FACULDADE DE ECONOMIA, ADMINISTRAÇÃO, CONTABILIDADE E CIÊNCIA DA INFORMAÇÃO E DOCUMENTAÇÃO - FACE

PROGRAMA DE PÓS-GRADUAÇÃO EM ADMINISTRAÇÃO - PPGA

LUIZ GONZAGA COSTA

\title{
A EVOLUÇÃO E A SUSTENTABILIDADE DA DÍVIDA PÚBLICA BRASILEIRA ENTRE 1995 E 2008
}




\section{LUIZ GONZAGA COSTA}

\section{A EVOLUÇÃO E A SUSTENTABILIDADE DA DÍVIDA PÚBLICA BRASILEIRA ENTRE 1995 E 2008}

Monografia apresentada ao Programa de Pós-Graduação em Administração (PPGA) da Faculdade de Economia, Administração, Contabilidade e Ciência da Informação e Documentação (FACE), da Universidade de Brasília, como requisito à obtenção do grau de Especialista em Orçamento e Finanças.

Orientador: Otavio Ladeira de Medeiros

Brasília - DF 
Aos meus pais José Ferreira da Costa e Ana Gonçalves Lara, que, através de palavras e exemplos me ensinaram a ter perseverança na realização dos meus objetivos, com ética e determinação. 


\section{AGRADECIMENTOS}

Ao meu orientador, professor Otavio Ladeira, que acolheu a proposta deste trabalho e se mostrou sempre receptivo e disposto a discutir as idéias.

À professora Fátima Bruno, pela paciência e competência nas orientações para elaboração do projeto desta monografia.

À minha irmã, Maria Aparecida da Costa, pelo carinho, paciência e apoio logístico durante a elaboração desta monografia.

Ao meu amigo, a quem considero como um filho, Alexandre Bianchi Junior, pela paciência e, sobretudo, compreensão pelos momentos de inevitável renúncia ao nosso convívio durante o curso e, principalmente, durante a elaboração desta monografia.

Aos meus colegas de trabalho pela paciência nos meus momentos de ansiedade proporcionada pelo acúmulo do trabalho com a elaboração desta monografia. Em especial, aos colegas Sílvia Regina e Fernando Travassos pelo apoio e revisões no projeto desta monografia.

À minha superintendente, Miyuki Abe, e às minhas chefes Carmen Pita e Neide Modrach, pela oportunidade que me ofereceram para realizar este curso.

E, por fim, aos professores e colegas de curso, que ajudaram a manter o clima agradável e propício à aprendizagem. Em especial, à colega Edilene dos Reis Rocha Araújo, pelo apoio nas discussões e ajuda na coleta dos dados utilizados neste trabalho. 


\section{RESUMO}

Esta monografia faz uma análise das contribuições dos principais fatores responsáveis pelo crescimento da dívida pública brasileira e, conseqüentemente, pela variação da relação DLSP/PIB, no período de 1995 a 2008. São apresentadas as contribuições das privatizações e concessões, dos passivos contingentes, da variação cambial, dos juros nominais, do resultado primário e do crescimento econômico. A idéia básica consiste em verificar, no contexto macroeconômico vigente no período mencionado, se o governo conseguiu fazer uma gestão no sentido de estabelecer uma relação equilibrada entre receitas, gastos e resultado primário de forma a estabilizar e reduzir a relação dívida/PIB, mantendo a sustentabilidade da dívida pública. É apresentada também a mudança no perfil da dívida pública brasileira, com demonstração da redução da dívida líquida externa e elevação da dívida líquida interna, no período considerado. Conclui-se que os resultados de redução da relação DLSP/PIB foram alcançados e a dívida pública se mostrou sustentável, no período analisado. Porém, esses resultados somente foram conseguidos graças à adoção, por parte do governo, de uma elevada carga tributária, que proporcionou superávits primários altos e crescentes, ao longo do período.

Palavras-chave: Dívida pública; juros; primário; crescimento econômico; sustentabilidade. 


\section{LISTA DE GRÁFICOS}

Gráfico 1. Evolução da DLSP/PIB Brasil - 1995 a 2008................................ 12

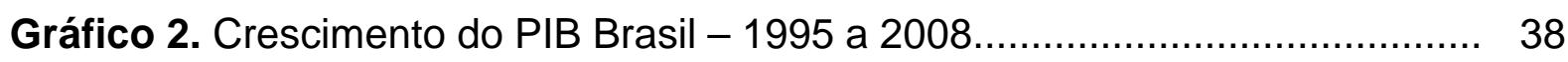

Gráfico 3. Efeito do crescimento do PIB sobre a DLSP - 1996 a 2008.............. 39

Gráfico 4. DLSP: externa, interna e total em relação ao PIB - 1995 a 2008....... 42

Gráfico 5. Evolução DLSP/PIB com e sem juros nominais - 1995 a 2008......... 44

Gráfico 6. Evolução DLSP/PIB com e sem juros, câmbio e primário - 1996 a

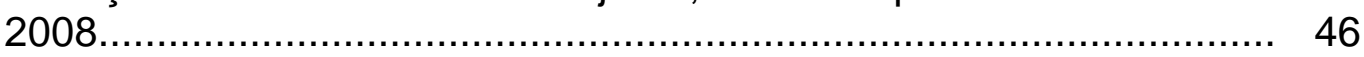

\section{LISTA DE TABELAS}

Tabela 1. Impactos das privatizações na variação DLSP/PIB - 1995 a 2008...... 22

Tabela 2. Impactos dos Passivos Contingentes na variação DLSP/PIB - 1996 a

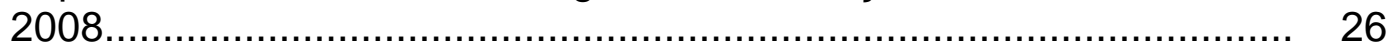

Tabela 3. Impactos da variação cambial na variação DLSP/PIB - 1996 a 2008... 30

Tabela 4. Impactos dos juros nominais na variação DLSP/PIB - 1995 a 2008.... 33

Tabela 5. Impactos do resultado primário na variação DLSP/PIB - 1995 a 2008. 36

\section{LISTA DE QUADROS}

Quadro 1. Evolução da DLSP - Fatores condicionantes. 


\title{
LISTA DE SIGLAS
}

\author{
BACEN - Banco Central do Brasil \\ BANERJ - Banco do Estado do Rio de Janeiro \\ BNDES - Banco Nacional de Desenvolvimento Econômico e Social \\ CBEE - Companhia Brasileira de Energia Emergencial \\ CIDE - Contribuição de Intervenção no Domínio Econômico \\ DLSP - Dívida Líquida do Setor Público \\ DFL - Dívida Fiscal Líquida \\ DNER - Departamento Nacional de Estradas e Rodagens \\ DPMF - Dívida Pública Mobiliária Federal \\ DPMFi - Dívida Pública Mobiliária Federal Interna \\ DPMFe - Dívida Pública Mobiliária Federal Externa \\ EMGEA - Empresa Gestora de Ativos \\ FCVS - Fundo de Compensação de Variações Salariais \\ FEPASA - Ferrovia Paulista S. A. \\ FGTS - Fundo de Garantia do Tempo de Serviço \\ GEIPOT - Empresa Brasileira de Planejamento de Transportes \\ IBGE - Instituto Brasileiro de Geografia e Estatística \\ IPEA - Instituto de Pesquisa Econômica Aplicada \\ IPI - Imposto sobre Produtos Industrializados \\ LDO - Lei de Diretrizes Orçamentárias \\ LRF - Lei de Responsabilidade Fiscal \\ LTN - Letra do Tesouro Nacional \\ NFSP - Necessidades de Financiamento do Setor Público \\ NTN - Nota do Tesouro Nacional \\ PIB - Produto Interno Bruto \\ REFIS - Programa de Recuperação Fiscal \\ RFFSA - Rede Ferroviária Federal S. A. \\ SELIC - Sistema Especial de Liquidação e Custódia \\ SUS - Sistema Único da Saúde \\ SRF - Secretaria da Receita Federal
}


STN - Secretaria do Tesouro Nacional

URV - Unidade Real de Valor 


\section{SUMÁRIO}

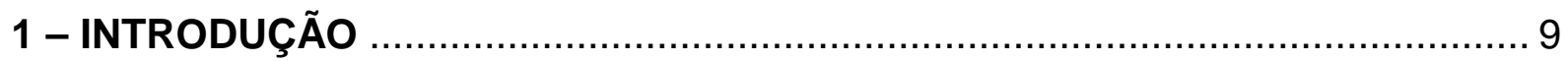

2 - FUNDAMENTAÇÃO TEÓRICA E ANÁLISE PRELIMINAR …......................... 11

2.1 - Atuação do Estado na gestão e sustentabilidade da dívida pública. 11

2.2 - Fatores que conduziram à variação da DLSP pós-Plano Real ........... 13

2.2.1 - As privatizações e as concessões ............................................. 19

2.2.2 - Os passivos contingentes ...................................................... 23

2.2.3 - A variação cambial ............................................................ 27

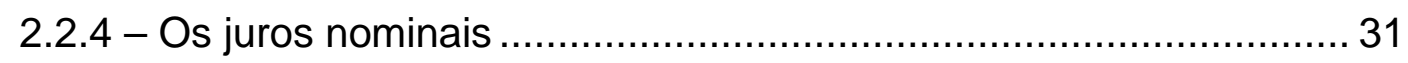

2.2 .5 - O resultado primário ................................................................ 34

2.2.6 - O crescimento econômico ……………………......................... 36

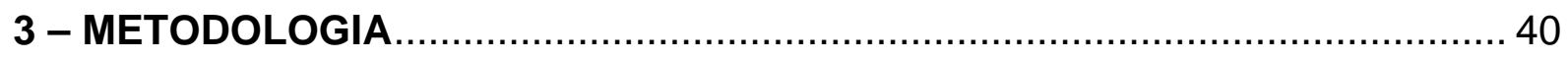

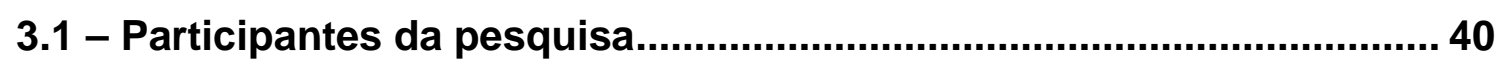

3.2 - Instrumentos e Procedimentos ....................................................... 40

4 - ANÁLISE DA EVOLUÇÃO DA DLSP E IMPACTOS DOS FATORES

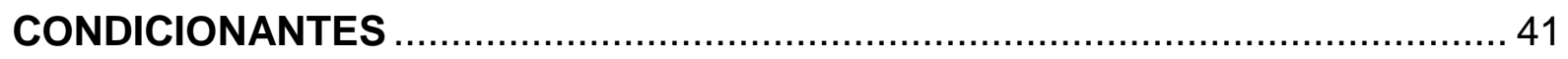

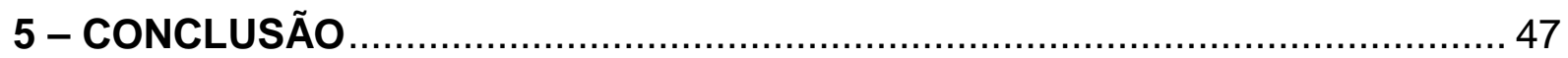

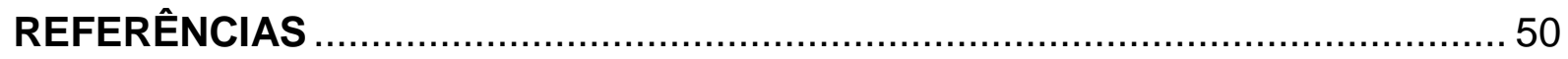




\section{1 - INTRODUÇÃO}

O crescimento da dívida pública brasileira e, principalmente, a evolução da relação DLSP/PIB, desde a implantação do Plano Real, têm sido os principais motivos de preocupação e discussão por parte dos formuladores de política econômica e de estudiosos do assunto. Analisando o período de 1995 a 2008, observa-se que a relação DLSP/PIB apresentou tendência crescente de 1995 a 2003 e tendência decrescente no restante do período. Devido a essa inversão na tendência da relação DLSP/PIB, as discussões e análises tratadas nesta monografia considerarão, na maioria das vezes, uma divisão do período em análise em dois períodos correspondentes a cada tendência.

De acordo com a série histórica do BACEN (2009), observaram-se durante esse período: i) crescente evolução da relação DLSP/PIB de 1995 (28,0\%) a 2003 $(52,4 \%)$ e redução gradual nos anos seguintes até 2008 (35,8\%); ii) elevação do superávit primário do setor público que passou de 0,1\% do PIB em 1996 para 4,0\% em 2008; iii) crescimento real médio do PIB de 3,2\%; e iv) taxas de juros elevadas, que chegaram a contribuir com $8,33 \%$ para o aumento da relação DLSP/PIB, em 2003. Assim, durante esse período o país passou por situações nas quais a credibilidade em relação à capacidade de honrar os seus compromissos em relação à dívida foi algumas vezes questionada pelos seus credores.

Vários fatores influenciaram essa variação da dívida durante o período 1995 2008. Alguns desses fatores foram decorrência da própria política econômica e da política de administração da dívida adotada pelo país. Porém, outros foram conseqüências das freqüentes instabilidades e crises econômicas que afetaram os países emergentes, inclusive o Brasil. Entre esses fatores, os principais classificamse por: i) peculiaridades da dívida em relação à sua estrutura de prazos e de indexação; ii) elevadas taxas de juros; iii) variação cambial; iv) variações no crescimento do PIB de 1995 a 2003, que melhorou e se estabilizou somente a partir de 2004; e v) reconhecimento de obrigações anteriores ocultas (passivos contingentes).

A preocupação com a deterioração da relação DLSP/PIB e das contas públicas sempre esteve presente na política econômica brasileira. Assim, a partir de 1999 um pacote de medidas anunciado pelo governo deu mais relevância a essa 
questão. Dentre essas medidas, se destacam no âmbito fiscal a imposição de metas de superávits fiscais, maior preocupação com redução de gastos em todos níveis do governo, elevação de tributos federais e a aprovação da Lei de Responsabilidade Fiscal em 2000. Essas medidas tiveram como objetivo evitar a continuidade da crescente evolução da relação DLSP/PIB, que se reverteu somente a partir de 2004.

O objetivo central desta monografia é apresentar e analisar os fatores que contribuíram para a variação da relação DLSP/PIB, buscando responder às seguintes questões: Quais foram os impactos das contribuições dos principais fatores que interferiram na variação da relação DLSP/PIB, entre 1995 e 2008, determinando a tendência crescente na primeira parte do período, e a tendência decrescente na segunda parte? Qual a importância das receitas das privatizações e concessões, e dos superávits primários para conter o crescimento da dívida pública no período em analise? Qual o impacto do reconhecimento de dívidas, e das taxas de juros praticadas, no crescimento da dívida pública no período em análise? Qual o impacto das variações cambiais, no crescimento da dívida pública no período em análise? Qual o impacto do crescimento econômico na variação da relação DLSP, ocorrida no período? E, finalmente, é possível afirmar que o Brasil encontrou um caminho para a gestão e sustentabilidade da sua dívida pública?

A estruturação desta monografia compreende cinco capítulos. O primeiro constitui-se desta introdução. O segundo aborda a fundamentação teórica onde são apresentados os principais conceitos e dados relativos aos fatores que contribuíram para a variação da relação DLSP/PIB, bem como a abordagem teórica relativa à sustentabilidade da dívida pública brasileira. O terceiro capítulo aborda a metodologia empregada para a realização da pesquisa e obtenção dos dados utilizados nas discussões, análises e avaliação da sustentabilidade da dívida pública brasileira. O quarto capítulo trata da discussão e análise dos dados obtidos no período em análise, para responder as questões formuladas acima, e apresenta também uma discussão sobre a mudança no perfil da dívida pública brasileira, com redução da dívida pública externa e aumento da dívida pública interna, no período em análise. $E$, o quinto e último capítulo apresenta as principais conclusões da monografia e apresentada também uma sugestão para trabalho futuro. 


\section{2 - FUNDAMENTAÇÃO TEÓRICA E ANÁLISE PRELIMINAR}

Neste capítulo será feita a fundamentação teórica que respaldará a pesquisa para obtenção dos dados que serão utilizados para avaliar a atuação do Estado na gestão e sustentabilidade da dívida pública brasileira. Será dada maior ênfase na variação da relação DLSP/PIB e no próprio crescimento do PIB, por ser essa relação um forte indicador de solvência do setor público, que representa a capacidade do país de honrar a dívida sem necessidade de aumentar impostos ou emitir moeda (BARBOSA, 2007).

Com o propósito de fundamentar a discussão sobre a evolução da dívida pública, serão apresentados os fatores que contribuíram para a variação da relação DLSP/PIB, com destaque para: as privatizações e concessões, os passivos contingentes, a variação cambial, os juros nominais, o resultado primário e o crescimento econômico.

\section{1 - Atuação do Estado na gestão e sustentabilidade da dívida pública}

A sustentabilidade da dívida pública e os impactos de um elevado nível de endividamento do setor público sobre a capacidade do governo de realizar políticas públicas, que produzam crescimento da economia, são assuntos relacionados aos principais temas econômicos atuais. Assim, essa capacidade é primordial para induzir os investimentos privados e ao mesmo tempo evitar as flutuações econômicas que reduzem a renda e o emprego. Porém, quando a relação DLSP/PIB se eleva muito, o governo se vê obrigado a transferir recursos que seriam usados em investimentos para o pagamento de despesas com juros e amortizações da dívida, e, tende a elevar os impostos. Dessa forma, o crescimento do PIB é um elemento que não pode ser desprezado quando se discute a evolução da dívida pública, considerando a sua importância na redução do nível de endividamento (OLIVEIRA, 2005).

A preocupação em relação à capacidade do governo de honrar seus compromissos tem estimulado vários autores a investigar se a dívida pública como proporção do PIB pode ou não ser considerada sustentável, ou seja, se a dívida 
pública continuaria apresentando comportamento crescente em virtude da condução das políticas monetária e fiscal vigentes, o que poderia comprometer a busca do crescimento sustentável da economia. Segundo Giambiagi e Além (2001), quanto maior for a dívida ou a taxa de juros, mais o governo necessita se ajustar para arcar com as despesas dos juros sem elevar a relação DLSP/PIB. Quanto maior for o crescimento da economia, menor será o esforço para manter a relação DLSP/PIB constante, pois, dessa forma, a dívida pode crescer mais sem afetar essa relação e sem que haja necessidade de aumentar o superávit primário. Assim, a necessidade de um superávit primário consistente com a sustentabilidade da dívida pública diminui com o crescimento da economia e cresce com o aumento da taxa de juros.

Desde a flutuação cambial e a implantação do Regime de Metas Inflacionárias em 1999, a política fiscal brasileira tem o objetivo de evitar que a relação dívida/PIB cresça e procura induzir a uma redução paulatina (CORREIA; MEURER, 2008). Entretanto, esta redução somente começou a ocorrer a partir de 2004.

O Gráfico 1 apresenta a evolução da DLSP em relação ao PIB ao final de cada ano do período em análise. Observa-se que a relação DLSP/PIB apresentou uma tendência crescente até 2003, quando atingiu 52,4\%. Nos cinco últimos anos do período, a relação apresentou tendência decrescente, chegando a 35,8\% em 2008.

\section{Gráfico 1}

\section{Evolução da DLSP/ PBBrasil - 1995 a2008}

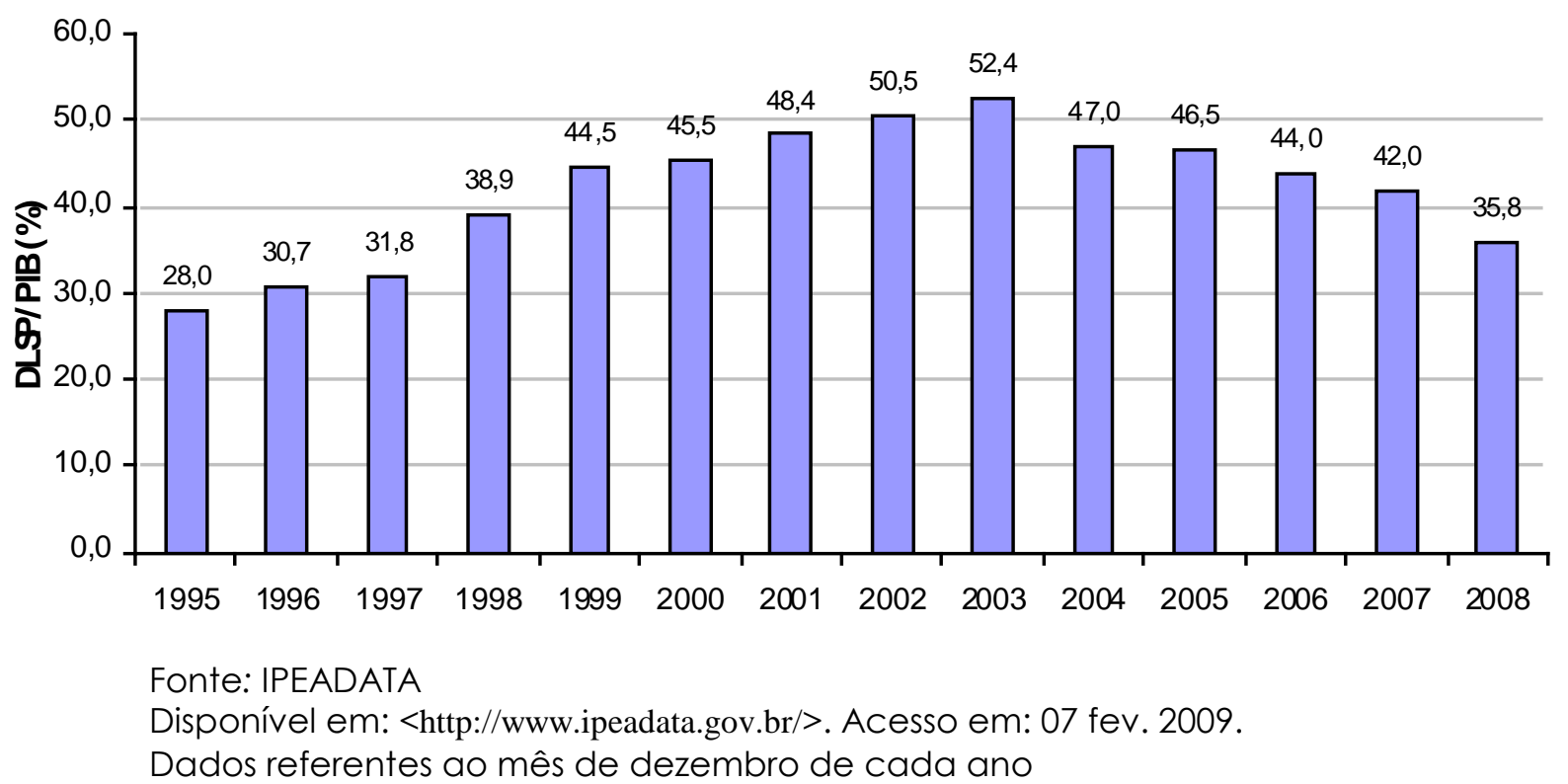


Embora o ajuste fiscal venha sendo a principal estratégia no gerenciamento da dívida pública, a sua condução tem sido prejudicada pelo perfil da dívida. Ao final de 1997, em função das crises financeiras internacionais, houve um incremento expressivo no patamar dos juros internos, gerando incerteza acerca do serviço da dívida e pondo em dúvida a capacidade futura de pagamento.

Visando se proteger de tais crises financeiras, em novembro de 1997 o governo federal anunciou um elenco de providências denominado "ajuste fiscal de curto prazo", na tentativa de preservar os benefícios já alcançados pelo Plano Real. Esse Programa de Estabilização Fiscal consistia em obter superávits primários no agregado dos três níveis de governo. De fato, a partir de 1999 passou-se a obter superávits primários significativos e sempre crescentes. Se por um lado o abrangente plano de estabilização fiscal buscou diminuir os desequilíbrios fiscais e o resgate da credibilidade da política fiscal, o perfil da dívida pública tornou-se um dos principais problemas no gerenciamento da esfera fiscal.

Com o objetivo de melhorar o perfil da dívida púbica, junto à necessidade de geração de superávits primários nas contas públicas, o Tesouro Nacional começou a implementar uma série de medidas, dentre as quais destacam-se: (i) organização dos vencimentos dos títulos em meses específicos (benchmarks), visando aumentar a liquidez e melhorar a precificação dos mesmos; (ii) operações de troca de títulos de curto prazo por prazos mais longos; (iii) realização de resgates antecipados, buscando reduzir o risco de refinanciamento e, no caso dos títulos indexados à inflação, também visando ao aumento da liquidez nesse mercado; (iv) melhora do saldo de caixa do Tesouro Nacional, mantendo o "colchão de liquidez" da dívida pública em níveis seguros; e (v) medidas para ampliação da base de investidores (CORREIA; MEURER, 2008).

\section{2 - Fatores que conduziram à variação da DLSP pós-Plano Real}

Nesta seção serão apresentados os principais fatores que contribuíram para a variação da dívida pública, bem como serão feitas análises preliminares sobre a contribuição de cada fator na variação da DLSP/PIB no período de 1995 a 2008.

O Plano Real, implantado em julho de 1994, efetuou um breve programa de ajuste das finanças públicas, na sua fase de inicial (GALLE; BERTOLLI, 2008). Já 
dentro de um contexto de prazo mais longo, foi necessário efetuar ajustes fiscais mais significativos, a fim de manter o seu sucesso na busca pela estabilização econômica.

O panorama das finanças públicas nos primeiros anos do Plano Real retratou uma situação de desajuste fiscal, com crescimento da dívida total do setor público brasileiro, motivado em parte pelo reconhecimento dos "esqueletos". Buscou-se compensar a dívida do reconhecimento dos "esqueletos" com as receitas das privatizações, porém, não se obteve o sucesso esperado. Para minimizar esse desajuste, foram adotadas algumas medidas como programas de ajuste fiscal e promulgação de leis de reformas no âmbito das três esferas de governo.

Com o reconhecimento dos "esqueletos" da dívida pública, houve explicitação de várias fontes de dívida pública, que até então não eram contabilizadas como tal. Dessa forma, o Governo Federal contribuiu para a transparência e a credibilidade das contas públicas, com o ônus da elevação da dívida pública.

As equações a seguir procuram explicitar os fatores que afetam a DLSP. São equações baseadas no modelo de Pinheiro (CARVALHO, 2001).

$$
D L S P_{T}=D M T+O D I_{T}+B_{T}+D E B T-R E S_{T}
$$

(dívida líquida do setor público)

$$
D F L T=D L S P T+P R I V T-P C_{T}
$$

(dívida fiscal líquida)

$$
\begin{aligned}
\Delta D F L t= & r 1 \cdot D M T+r 2 \cdot O D I T+r^{\prime} \cdot E \cdot D E B T-r^{\prime} \cdot E \cdot R E S_{T}-S P R I M_{t} \\
& (\text { necessidades nominais de financiamento do setor público) }
\end{aligned}
$$

Onde:

$\boldsymbol{D L S P}=$ dívida líquida do setor público;

$\boldsymbol{D F L}=$ dívida fiscal líquida;

$\boldsymbol{T}=$ tempo no final do período (referências para estoques);

$\boldsymbol{t}=$ período de tempo entre $T$ e $(T+1)$ (referência para fluxos);

$\Delta=$ indica variação;

$\boldsymbol{D} \boldsymbol{M}$ = estoque de dívida mobiliária interna total;

SPRIM = superávit primário consolidado do setor público;

$\boldsymbol{R} \boldsymbol{E} \boldsymbol{S}$ = estoque de reservas internacionais (liquidez internacional); 
$\boldsymbol{B}=$ estoque de base monetária líquida dos ativos públicos sem rendimento (arrecadações a recolher e depósitos à vista);

$\boldsymbol{P R I V}=$ privatização ao longo do período $t$, decorrente do processo de alienação de empresas estatais;

$\boldsymbol{P C}=$ passivos contingentes ao longo do período $t$, decorrente do processo de reconhecimento de dívidas;

$\boldsymbol{O D I}=$ outras dívidas internas (exclusive dívida mobiliária interna), líquidas de ativos públicos internos (ativos financeiros);

$\boldsymbol{D E B}=$ estoque de dívida externa pública bruta;

$\boldsymbol{r} \mathbf{1}=$ fatores de atualização dos títulos da dívida mobiliária interna (DM) (indexadores mais taxas de juros);

$\boldsymbol{r} \mathbf{2}=$ fatores de atualização das outras dívidas internas líquidas (ODI);

$\boldsymbol{r}^{\prime}{ }^{\prime}=$ fator de atualização da dívida externa pública bruta em US\$;

$\boldsymbol{r}^{\prime}=$ taxa de juros que remunera as reservas internacionais; $\mathrm{e}$

$\boldsymbol{E}=$ taxa de câmbio nominal (dólar comercial venda) de fim de período (estoques), ou média do período (fluxos);

As equações (1) e (2) procuram expressar as posições dos estoques das dívidas do setor público e a equação (3) procura determinar o fluxo relativo às necessidades nominais de financiamento do setor público.

A equação (1) é a definição da Dívida Líquida do Setor Público; a equação (2) define a Dívida Fiscal Líquida, que corresponde à DLSP ajustada em relação às privatizações e aos passivos contingentes, retirando os efeitos temporários desses fatores; e a equação de fluxo (3) equivale à própria definição da NFSP, em seus diversos conceitos e componentes, haja vista a $\triangle D F L$ objetiva buscar os elementos permanentes do esforço fiscal e não os efeitos temporários de outros elementos.

Vale destacar que a dívida mobiliária federal é o principal item da DLSP, não apenas pela magnitude dos estoques, mas também pela dinâmica de crescimento e implicações para as políticas monetária e fiscal.

A análise da relação DLSP/PIB requer a estimação mensal do PIB, pois o IBGE divulga o resultado agregado com periodicidades trimestral e anual, enquanto os dados fiscais são mensais. Além disso, existe a defasagem da divulgação dessas estatísticas, com os dados fiscais sendo divulgados até trinta dias após 0 encerramento do mês e os valores nominais do PIB disponibilizados em torno de noventa dias após o final de cada trimestre. 
Assim, com o objetivo de realizar a divulgação mensal da relação DLSP/PIB com defasagem reduzida, o Banco Central estima o PIB mensal da economia brasileira. Os fluxos mensais do PIB podem ser expressos em termos reais ou nominais, podendo ser contabilizados em valores correntes ou valorizados para um determinado período com a utilização de um índice de preços (BACEN, 2004).

A seguir, será apresentada a dinâmica da dívida líquida do setor público brasileiro, evidenciando os fatores: privatizações e concessões, passivos contingentes ou "esqueletos" (como são chamados alguns desses passivos contingentes), variação cambial, juros nominais, resultado primário e crescimento econômico. Vale observar que não serão isoladas as interferências políticas e institucionais que, de certa forma, poderão ter influenciado também a dinâmica da dívida pública brasileira. Os dados considerados serão basicamente os dados apresentados no Quadro 1. 
Quadro 1 - Evolução da DLSP - Fatores condicionantes

\begin{tabular}{|c|c|c|c|c|c|c|c|}
\hline \multicolumn{8}{|c|}{ Fluxos acumulados no ano - R\$ milhões } \\
\hline Discriminação & Dez/1996 & Dez/1997 & Dez/1998 & Dez/1999 & Dez/2000 & Dez/2001 & Dez/2002 \\
\hline Dívida líquida total - saldo & 269193 & 308426 & 385870 & 516579 & 563163 & 660867 & 881108 \\
\hline Dívida líquida - var. ac. ano & 60733 & 39233 & 77443 & 130709 & 46584 & 97704 & 220241 \\
\hline Fatores condicionantes: ${ }^{1 /}$ & 60733 & 39233 & 77443 & 130709 & 46584 & 97704 & 220241 \\
\hline NFSP & 44968 & 51626 & 68229 & 56284 & 39806 & 42788 & 61614 \\
\hline Primário & 740 & 8310 & -106 & -31087 & - 38157 & -43656 & -52390 \\
\hline Juros nominais & 44229 & 43317 & 68335 & 87372 & 77963 & 86444 & 114004 \\
\hline Ajuste cambial & 1530 & 4114 & 6859 & 69384 & 18344 & 30840 & 147225 \\
\hline Dívida mobiliária interna indexada ao câmbio & 1013 & 1606 & 4261 & 39873 & 9479 & 19182 & 76662 \\
\hline Dívida externa - metodológico & 517 & 2509 & 2598 & 29511 & 8864 & 11658 & 70564 \\
\hline Dívida externa - outros ajustes ${ }^{2 /}$ & -241 & 0 & -6 & 0 & 0 & -383 & 753 \\
\hline Reconhecimento de dívidas & 15220 & -207 & 15216 & 14014 & 8672 & 25439 & 14286 \\
\hline Privatizações & -745 & -16301 & -12854 & -8973 & -20238 & -981 & -3637 \\
\hline PIB acumulado em doze meses - valorizado & 876300 & 968874 & 990978 & 1159973 & 1236538 & 1364379 & 1745822 \\
\hline Dívida líquida total - saldo & 30,7 & 31,8 & 38,9 & 44,5 & 45,5 & 48,4 & 50,5 \\
\hline Dívida líquida - var. ac. ano & 2,7 & 1,1 & 7,1 & 5,6 & 1,0 & 2,9 & 2,0 \\
\hline Fatores condicionantes: ${ }^{1 /}$ & 6,9 & 4,0 & 7,8 & 11,3 & 3,8 & 7,2 & 12,6 \\
\hline NFSP & 5,1 & 5,3 & 6,9 & 4,9 & 3,2 & 3,1 & 3,5 \\
\hline Primário & 0,1 & 0,9 & 0,0 & $-2,7$ & $-3,1$ & $-3,2$ & $-3,0$ \\
\hline Juros nominais & 5,0 & 4,5 & 6,9 & 7,5 & 6,3 & 6,3 & 6,5 \\
\hline Ajuste cambial & 0,2 & 0,4 & 0,7 & 6,0 & 1,5 & 2,3 & 8,4 \\
\hline Dívida mobiliária interna indexada ao câmbio & 0,1 & 0,2 & 0,4 & 3,4 & 0,8 & 1,4 & 4,4 \\
\hline Dívida externa - metodológico & 0,1 & 0,3 & 0,3 & 2,5 & 0,7 & 0,9 & 4,0 \\
\hline Dívida externa - outros ajustes ${ }^{2 /}$ & 0,0 & 0,0 & 0,0 & 0,0 & 0,0 & 0,0 & 0,0 \\
\hline Reconhecimento de dívidas & 1,7 & 0,0 & 1,5 & 1,2 & 0,7 & 1,9 & 0,8 \\
\hline Privatizações & $-0,1$ & $-1,7$ & $-1,3$ & $-0,8$ & $-1,6$ & $-0,1$ & $-0,2$ \\
\hline Efeito do crescimento do PIB sobre a dívida ${ }^{3 /}$ & $-4,2$ & $-2,9$ & $-0,7$ & $-5,7$ & $-2,8$ & $-4,3$ & $-10,6$ \\
\hline
\end{tabular}

1/ Os fatores condicionantes da dívida líquida como percentual do PIB consideram o total dos fatores, dividido pelo PIB acumulado nos últimos 12 meses valorizado, segundo a fórmula: ( $\sum_{\text {FatoresCondicionantes }} / \mathrm{PIB}_{12 \mathrm{Meses} V a \text { lorizado }}{ }^{*} 100$. Não reflete a variação da dívida em percentagem do $\mathrm{PIB}$.

2/ Inclui ajuste de paridade da cesta de moedas que integram as reservas internacionais e a dívida externa, e demais ajustes da área externa.

3/ Considera a variação da relação dívida/PIB devida ao crescimento verificado no PIB, calculada pela fórmula: $\mathrm{D}_{\mathrm{t}-1} /\left(\mathrm{PIB}_{\mathrm{Mes} A t u a l} / \mathrm{PIB}_{\text {MesBase }}\right)$ - $\mathrm{D}_{\mathrm{t}-1}$.

* Dados preliminares.

Divida Dez1995 208460

Pib Dez1995 745091

Div/Pib Dez1995 28

Fonte: BACEN

Disponível em: < http://www.bcb.gov.br/?FATORESDLSP>. Acesso em: 31 mar.2009 


\section{Quadro 1 - Evolução da DLSP - Fatores condicionantes (continuação)}

\begin{tabular}{|c|c|c|c|c|c|c|}
\hline \multicolumn{7}{|c|}{ Fluxos acumulados no ano - R\$ milhões } \\
\hline Discriminação & Dez/2003 & Dez/2004 & Dez/2005 & Dez/2006 & Dez/2007 & Dez/2008 \\
\hline Dívida líquida total - saldo & 913145 & 956996 & 1002485 & 1067363 & 1150357 & 1069579 \\
\hline Dívida líquida - var. ac. ano & 32037 & 43851 & 45488 & 64879 & 82994 & -80778 \\
\hline Fatores condicionantes: ${ }^{1 /}$ & 32037 & 43851 & 45488 & 64879 & 82994 & -80778 \\
\hline NFSP & 79037 & 47144 & 63641 & 69883 & 57926 & 44307 \\
\hline Primário & -66173 & -81112 & -93505 & -90144 & -101606 & -118037 \\
\hline Juros nominais & 145210 & 128256 & 157146 & 160027 & 159532 & 162344 \\
\hline Ajuste cambial & -64307 & -16193 & -18202 & -4881 & 29268 & -98217 \\
\hline Dívida mobiliária interna indexada ao câmbio & -22715 & -3335 & -4554 & -2222 & -2432 & 3180 \\
\hline Dívida externa - metodológico & -41592 & -12858 & -13648 & -2659 & 31701 & -101397 \\
\hline Dívida externa - outros ajustes ${ }^{2 /}$ & 16703 & 7139 & -2258 & 2302 & -2305 & -26236 \\
\hline Reconhecimento de dívidas & 605 & 6514 & 3262 & -375 & -630 & 135 \\
\hline Privatizações & 0 & -753 & -954 & -2049 & -1265 & -767 \\
\hline PIB acumulado em doze meses - valorizado & 1744123 & 2036783 & 2157437 & 2424641 & 2736836 & 2986154 \\
\hline Dívida líquida total - saldo & 52,4 & 47,0 & 46,5 & 44,0 & 42,0 & 35,8 \\
\hline Dívida líquida - var. ac. ano & 1,9 & $-5,4$ & $-0,5$ & $-2,4$ & $-2,0$ & $-6,2$ \\
\hline Fatores condicionantes: ${ }^{1 /}$ & 1,8 & 2,2 & 2,1 & 2,7 & 3,0 & $-2,7$ \\
\hline NFSP & 4,5 & 2,3 & 2,9 & 2,9 & 2,1 & 1,5 \\
\hline Primário & $-3,8$ & $-4,0$ & $-4,3$ & $-3,7$ & $-3,7$ & $-4,0$ \\
\hline Juros nominais & 8,3 & 6,3 & 7,3 & 6,6 & 5,8 & 5,4 \\
\hline Ajuste cambial & $-3,7$ & $-0,8$ & $-0,8$ & $-0,2$ & 1,1 & $-3,3$ \\
\hline Dívida mobiliária interna indexada ao câmbio & $-1,3$ & $-0,2$ & $-0,2$ & $-0,1$ & $-0,1$ & 0,1 \\
\hline Dívida externa - metodológico & $-2,4$ & $-0,6$ & $-0,6$ & $-0,1$ & 1,2 & $-3,4$ \\
\hline Dívida externa - outros ajustes ${ }^{2 /}$ & 1,0 & 0,4 & $-0,1$ & 0,1 & $-0,1$ & $-0,9$ \\
\hline Reconhecimento de dívidas & 0,0 & 0,3 & 0,2 & 0,0 & 0,0 & 0,0 \\
\hline Privatizações & 0,0 & 0,0 & 0,0 & $-0,1$ & 0,0 & 0,0 \\
\hline Efeito do crescimento do PIB sobre a dívida ${ }^{3 /}$ & 0,0 & $-7,5$ & $-2,6$ & $-5,1$ & $-5,0$ & $-3,5$ \\
\hline
\end{tabular}

1/ Os fatores condicionantes da dívida líquida como percentual do PIB consideram o total dos fatores, dividido pelo PIB acumulado nos últimos 12 meses valorizado, segundo a fórmula: $\left(\sum_{\text {Fatores Condicionantes }} / \mathrm{PIB}_{12 \mathrm{M} \text { esesValorizado }}{ }^{*} 100\right.$. Não reflete a variação da dívida em percentagem do $\mathrm{PIB}$.

2/ Inclui ajuste de paridade da cesta de moedas que integram as reservas internacionais e a dívida externa, e demais ajustes da área externa.

3/ Considera a variação da relação dívida/PIB devida ao crescimento verificado no PIB, calculada pela fórmula: $D_{t-1} /\left(P_{I} B_{\text {MesAtual }} / P_{1} B_{\text {MesBase }}\right)$ - $D_{t-1}$

* Dados preliminares.

$\begin{array}{lr}\text { Divida Dez1995 } & 208460 \\ \text { Pib Dez1995 } & 745091 \\ \text { Div/Pib Dez1995 } & 28\end{array}$

Fonte: BACEN

Disponível em: < http://www.bcb.gov.br/?FATORESDLSP>. Acesso em: 31 mar.2009 


\subsection{1 - As privatizações e as concessões}

Nesta subseção será apresentada uma descrição das privatizações e concessões, com os impactos de suas receitas na redução da DLSP/PIB, no período de 1995 a 2008.

Inicialmente, vale esclarecer que, embora o Programa Nacional de desestatização (PND) autorize providências para concessões e privatizações (CARVALHO FILHO, 2008), existe diferença entre concessão e privatização. Conceder não é "vender" uma propriedade estatal, mas sim permitir que uma empresa privada explore determinado patrimônio, com obrigação de efetuar melhorias, sendo que o Estado continua titular do bem. Alguns exemplos de concessões são os serviços de telecomunicações e as rodovias. As rodovias não foram vendidas e quando terminar o prazo de duração dos contratos, elas retornarão ao Estado com todos os benefícios, melhorias e ampliações que foram feitas (ARTESP, 2007).

As privatizações brasileiras iniciaram-se de forma lenta e gradual, tomando impulso apenas com o lançamento do Programa Nacional de Desestatização (PND) em 1990. Este programa passou a constituir um importante instrumento de política econômica, incluído em um amplo conjunto de reformas estruturais voltadas para a reformulação do papel do Estado brasileiro, que passaria a ter uma função mais reguladora e menos produtora, como destaca Carvalho (2001).

Apesar da existência de um ambiente favorável às privatizações, foi necessária a transposição de vários obstáculos, tais como: resistência política, resistência de grupos contrários à privatização, complexidade das estatais brasileiras de maior porte e escolha dos modelos de venda das empresas.

Em muitos casos, quando uma estatal foi privatizada, os recursos obtidos com a privatização não pertenciam diretamente à União, mas à estatal controladora da empresa alienada. Isso ocorreu, por exemplo, quando as empresas vendidas eram subsidiárias ou coligadas de estatais nas quais o Tesouro era o acionista majoritário. Dessa forma, o alienante não era o Tesouro, mas uma estatal sobre a qual este detinha o controle direto. Assim sendo, o caminho percorrido pelos recursos obtidos com a privatização para o caixa do Tesouro tornava-se mais lento do que se as ações do Tesouro na controladora fossem vendidas.

As receitas de privatização foram transitórias, de forma que a privatização foi encarada como um instrumento auxiliar das políticas fiscal e econômica. Caso o 
governo privatizasse suas empresas e não promovesse um esforço continuado de ajuste em suas contas, certamente haveria problemas de sustentabilidade da dívida pública no futuro.

As receitas provenientes das privatizações financiaram gastos de consumo do governo e investimentos, e pagaram juros relativo à dívida pública, especialmente relativos à dívida interna. Em relação ao financiamento, receitas de privatização provocaram efeitos positivos sobre as variações das dívidas interna e externa.

As receitas das privatizações, quando utilizadas para pagar dívida pública, permitiram redução dos dispêndios financeiros líquidos do governo e do estoque da dívida. A redução do estoque da dívida resultou em redução no pagamento de juros.

Adicionalmente, as privatizações tiraram do setor público a responsabilidade de novos investimentos nas empresas privatizadas. Dessa forma, apenas o fato de o Estado passar a responsabilidade de investir para o setor privado teve impacto fiscal positivo. Além disso, no caso de empresas deficitárias, o Tesouro Nacional se eximiu da responsabilidade de realizar novos aportes de capital para investimentos nas mesmas.

Entretanto, para tornar uma empresa a ser privatizada atrativa aos potenciais compradores do setor privado, em muitos casos, foram necessárias operações de saneamento financeiro. Tais operações constituíram-se de capitalizações, reescalonamentos e assunções de dívidas e outros passivos. Essas operações acabariam ocorrendo independentemente da privatização. Porém, com a privatização, o saneamento financeiro foi antecipado.

A destinação das receitas de privatização no Brasil encontrava-se definida em dispositivos legais e dependia do tipo de alienante. As receitas de privatização foram utilizadas, prioritariamente, na amortização da dívida pública interna, dada a sua importância.

Ao se destinarem os recursos das privatizações à dívida interna, a redução do estoque e melhoria do perfil da dívida pública do Tesouro ocorreu por meio:

- Da aplicação de parte ou totalidade dos recursos arrecadados, em moeda corrente, no resgate de títulos da dívida pública mobiliária federal de emissão do Tesouro;

- Do aumento dos prazos de vencimento de títulos e créditos diversos (moedas de privatização), de posse de empresas da Administração 
Indireta, por meio da substituição desses papéis por NTN-P (permuta de papéis de prazos mais curtos por títulos públicos de longo prazo); e

- De baixa do estoque de moedas de privatização, quando do seu recebimento pelo Tesouro Nacional, seja diretamente, ou em decorrência das operações de clearing.

Os recursos que ingressaram no caixa do Tesouro, decorrentes das privatizações realizadas, contribuíram de forma importante para a administração da Dívida Pública Mobiliária Federal Interna (DPMFi), em razão do elevado volume de receitas utilizadas para abater a dívida mobiliária federal de emissão do Tesouro Nacional.

A utilização de receitas de privatização para abater dívida mobiliária federal possibilitou a colocação de menores lotes de títulos competitivos nos leilões subseqüentes ao emprego dos recursos. Assim, ao ser ofertado um menor volume de títulos num leilão, o prêmio cobrado pelo mercado foi menor, representando menores custos para o Tesouro. Outro efeito indireto foi a melhoria das expectativas dos agentes, uma vez que aumentou a credibilidade do governo, o que também contribuiu para reduzir os custos do Tesouro.

Na tabela 1, são apresentados os impactos das receitas de privatizações e concessões para diminuir a relação DLSP/PIB no período de 1995 a 2008. 
Tabela 1

Impactos das privatizações na variação DLSP/PIB - 1995 a 2008

( $R$ \$ milhões)

\begin{tabular}{r|r|r|r}
\hline Ano & Privatizações & $\begin{array}{r}\text { PIB acum. } \\
\text { doze meses } \\
\text { - valorizado }\end{array}$ & $\begin{array}{r}\text { Impacto Priv. } \\
\text { na DLSP/PIB }\end{array}$ \\
\hline 1995 & 1.145 & 745.091 & 0,15 \\
\hline 1996 & 745 & 876.300 & 0,09 \\
\hline 1997 & 16.301 & 968.874 & 1,68 \\
\hline 1998 & 12.854 & 990.978 & 1,30 \\
\hline 1999 & 8.973 & 1.159 .973 & 0,77 \\
\hline 2000 & 20.238 & 1.236 .538 & 1,64 \\
\hline 2001 & 981 & 1.364 .379 & 0,07 \\
\hline 2002 & 3.637 & 1.745 .822 & 0,21 \\
\hline 2003 & 0 & 1.744 .123 & 0,00 \\
\hline 2004 & 753 & 2.036 .783 & 0,04 \\
\hline 2005 & 954 & 2.157 .435 & 0,04 \\
\hline 2006 & 2.049 & 2.424 .641 & 0,08 \\
\hline 2007 & 1.265 & 2.736 .836 & 0,05 \\
\hline 2008 & 767 & 2.986 .154 & 0,03 \\
\hline
\end{tabular}

Fonte: BACEN

Elaboração do autor

Nos anos de 1995 e 1996, as receitas de privatizações e concessões corresponderam a $0,15 \%$ do PIB e $0,09 \%$ do PIB, respectivamente, representando impacto muito baixo na redução da relação DLSP/PIB.

Nos anos de 1997 a 2000, foi observado o maior impacto das receitas de privatizações e concessões na redução da DLSP/PIB dentro do período considerado. Apesar desse impacto, a relação DLSP/PIB se manteve crescente nesses anos, motivada por outros fatores que serão visto posteriormente.

Nos demais anos, de 2001 a 2008, as receitas de privatizações e concessões representaram impacto muito baixo na redução da relação DLSP/PIB. Sendo que, no ano 2003 não se obteve receita de privatização. 


\subsection{2 - Os passivos contingentes}

Nesta subseção será apresentada uma descrição dos passivos contingentes, com os impactos do reconhecimento dessas dívidas na variação da DLSP/PIB, no período de 1996 a 2008.

Das várias definições existentes para os passivos contingentes, destaca-se aqui a do BACEN: "dívidas do setor público, geradas no passado, e que já produziram impacto macroeconômico e, ao serem reconhecidas pelo Governo Federal, passam a ser contabilizadas no quadro da DLSP" (PÊGO FILHO; PINHEIRO, 2004).

Com base nas definições supracitadas, entende-se que todo "esqueleto" dívida em processo de reconhecimento e cujos fatos geradores e impactos macroeconômicos e fiscais diretos situam-se no passado - é um passivo contingente, mas nem todo passivo contingente é, necessariamente, um esqueleto. O adjetivo "contingente" tem conotação de "condicional", "potencial" e "provável", indicando que o fato gerador da obrigação do governo depende de fatores imprevisíveis. Assim, o passivo contingente se associa à possibilidade de ocorrência ou de não ocorrência do evento gerador da obrigação do setor público (STN, 2003).

De acordo com Pêgo Filho e Pinheiro (2004), na LDO 2004 (Anexo XIX; $\S \S 3.1-3.6)$, os passivos contingentes no Brasil são classificados em seis categorias, a saber:

a) Passivos que resultam de controvérsias sobre indexação e controles de preços praticados durante planos de estabilização e que derivam, também, das soluções propostas para sua compensação (p. ex.: correção dos cruzados bloqueados pelo Plano Collor em 1990, ações trabalhistas referentes à aplicação da Unidade Real de Valor (URV) em 1994, ações impetradas por entidades conveniadas ao Sistema Único de Saúde (SUS), ações do setor sucro-alcooleiro e percentual de reajuste dos saldos do Fundo de Garantia do Tempo de Serviço (FGTS));

b) Passivos decorrentes de lides de ordem tributária e Previdenciária (p. ex.: ações das empresas excluídas do cadastro do programa de Recuperação Fiscal (REFIS), ações que reivindicam créditos fiscais decorrentes do Imposto sobre Produtos Industrializados (IPI) - exportação, questionamentos quanto à cobrança da Contribuição de Intervenção no 
Domínio Econômico (CIDE) e empréstimo compulsório sobre o consumo de combustíveis e compra de veículos no governo Sarney);

c) Questões judiciais pertinentes à administração do Estado, como as privatizações, a extinção dos órgãos, a liquidação de empresas e atos que afetam a administração de pessoal (p. ex:: obrigações trabalhistas da Rede Ferroviária Federal S. A. (RFFSA), da Ferrovia Paulista S. A. (FEPASA), da Empresa Brasileira de Planejamento de Transportes (GEIPOT) e do Departamento Nacional de Estradas e Rodagem (DNER));

d) Os chamados "esqueletos" ou dívidas passadas em processo de reconhecimento (p. ex.: dívidas relativas ao Fundo de Compensação de Variações Salariais (FCVS). Em fevereiro de 2003, as dívidas totais em reconhecimento estavam estimadas em $R \$ 77,8$ bilhões, onde somente 0 FCVS alcançava $R \$ 70,7$ bilhões);

e) Ativos decorrentes de operações de liquidação extrajudicial de instituições financeiras, além de créditos contra o FCVS e os Estados, registrados no balanço do Banco Central (p. ex.: ativos decorrentes de liquidação extrajudicial de alguns bancos públicos, como os do BANERJ e os do Banco Econômico, além de créditos contra o FCVS e os Estados, registrados no Banco Central.); e

f) Operações prestadas (aval e garantia) pela União aos demais entes da Federação e às empresas estatais (p.ex.: ações impetradas por empregados ativos e aposentados de empresas estatais, reivindicando a reposição de expurgos inflacionários decorrentes dos diversos planos de estabilização, avais concedidos a estados e municípios, operações contabilizadas pela Empresa Gestora de Ativos (EMGEA), garantias junto à Companhia Brasileira de Energia Emergencial (CBEE) e ações judiciais contra as estatais federais patrocinadoras de planos de benefícios administrados por entidades fechadas de previdência privada).

A formação de um "esqueleto", no caso do Brasil, ocorre porque o financiamento do setor privado ao governo não implica em influxo imediato de recursos para as contas públicas. Isso acontece, por exemplo, quando o setor público garante preços subsidiados aos consumidores de certos bens ou serviços, comprometendo-se, simultaneamente, a repassar o diferencial de preços aos produtores desses bens ou serviços. Esses subsídios podem, com o tempo, gerar 
volumosos passivos do governo junto às instituições financeiras oficiais, que são, normalmente, as financiadoras dessas atividades. O FCVS é um exemplo disso.

Em 1996, acreditava-se que, daquele ano em diante, o reconhecimento de passivos contingentes seria, no máximo, equivalente aos valores anuais das privatizações totais. Isso configuraria uma política de gestão do ajuste patrimonial do setor público tendente a impedir que esse ajuste pressionasse liquidamente a dívida. Entretanto, em virtude da grande quantidade de ações judiciais contra a privatização essa meta informal não foi alcançada. O reconhecimento de passivos contingentes líquidos anuais superou, sistematicamente, o ajuste de privatizações, contribuindo para aumentar a dívida e levando o governo a ter que aumentar sua meta de superávit primário (PÊGO FILHO; PINHEIRO, 2003).

No sentido de aumentar a transparência e a prestação de contas à sociedade, o Banco Central do Brasil passou a explicitar, a partir de 1996, o reconhecimento dos passivos contingentes.

$\mathrm{Na}$ tabela 2, são apresentados os impactos do reconhecimento das dívidas relativas aos passivos contingentes na variação da relação da DLSP/PIB, ocorrida no período de 1996 a 2008. 
Tabela 2

Impactos dos Passivos Contingentes na variação DLSP/PIB - 1996 a 2008

( $R$ \$ milhões)

\begin{tabular}{l|r|r|r|r|r}
\hline Ano (1) & $\begin{array}{c}\text { Passivos } \\
\text { Contingentes } \\
\mathbf{( 2 )}\end{array}$ & $\begin{array}{c}\text { PIB acum. } \\
\text { doze meses } \\
- \text { valorizado }\end{array}$ & $\begin{array}{c}\text { Impacto } \\
\text { Pass. Cont. } \\
\text { na DLSP/PIB }\end{array}$ & $\begin{array}{c}\text { Impacto } \\
\text { Privatizaçōes }\end{array}$ & $\begin{array}{c}\text { Imass. Cont. - } \\
\text { Privatizações } \\
\text { na DLSP/PIB }\end{array}$ \\
\hline 1996 & -15.220 & 876.300 & $-1,74$ & -14.475 & $-1,65$ \\
\hline 1997 & 207 & 968.874 & 0,02 & 16.508 & 1,70 \\
\hline 1998 & -15.216 & 990.978 & $-1,54$ & -2.362 & $-0,24$ \\
\hline 1999 & -14.014 & 1.159 .973 & $-1,21$ & -5.041 & $-0,43$ \\
\hline 2000 & -8.672 & 1.236 .538 & $-0,70$ & 11.566 & 0,94 \\
\hline 2001 & -25.439 & 1.364 .379 & $-1,86$ & -24.458 & $-1,79$ \\
\hline 2002 & -14.286 & 1.745 .822 & $-0,82$ & -10.649 & $-0,61$ \\
\hline 2003 & -605 & 1.744 .123 & $-0,03$ & -605 & $-0,03$ \\
\hline 2004 & -6.514 & 2.036 .783 & $-0,32$ & -5.761 & $-0,28$ \\
\hline 2005 & -3.262 & 2.157 .435 & $-0,15$ & -2.308 & $-0,11$ \\
\hline 2006 & 375 & 2.424 .641 & 0,02 & 2.424 & 0,10 \\
\hline 2007 & 630 & 2.736 .836 & 0,02 & 1.895 & 0,07 \\
\hline 2008 & -135 & 2.986 .154 & $-0,01$ & 632 & 0,02 \\
\hline
\end{tabular}

Fonte: BACEN

Elaboração do autor

(1) Devido à falta de disponibilidade das informações dos passivos contingentes em 1995 , são apresentados os dados a partir de 1996.

(2) Nem sempre a explicitação de passivos provoca elevação da DLSP. Basta para isso que o reconhecimento desses passivos envolva um "lastro" em ativos de igual valor. Assim, no tocante ao impacto direto sobre a dívida pública, pode-se falar em duas categorias de passivos contingentes: os que aumentam diretamente a dívida líquida e os que, sendo lastreados em novos ativos, não têm efeito imediato sobre a DLSP. Além disso, o Tesouro pode reconhecer também ativos, os chamados ativos contingentes ou, em linguagem jornalística, "esqueletos às avessas". Isso tende a compensar o ajuste patrimonial, anulando o efeito dos "esqueletos" sobre a DLSP, o que explica os resultados dos passivos contingentes nos anos de 1997, 2006 e 2007.

O período em que os passivos contingentes contribuíram mais para a elevação da relação DLSP/PIB corresponde aos primeiros anos em que se iniciou a prática de reconhecimento dessas dívidas. Nos anos de 1996 a 2002 (excetuandose o ano de 1997, quando o valor dos ativos contingentes foi superior ao valor dos passivos contingentes, contribuindo em $0,02 \%$ para redução da DLSP/PIB), foi o 
período em que o reconhecimento das dívidas dos passivos contingentes representou maior impacto na elevação da relação DLSP/PIB.

Em 2003, ano com maior valor da relação DLSP/PIB (52,4\%) no período analisado, os passivos contingentes contribuíram apenas com $0,03 \%$ do PIB para elevação dessa relação.

Nos anos de 2004 a 2008, período em que ocorreu forte redução na relação DLSP/PIB, caindo de $47,0 \%$ em 2004 para $35,8 \%$ em 2008, os passivos contingentes não tiveram impacto significativo nessa relação. Inclusive, nos anos de 2006 e 2007, como ocorreu em 1997, o resultado dos ativos contingentes menos os passivos contingentes foi favorável em $0,02 \%$ para redução da DLSP/PIB.

Quanto à meta informal de que, de 1996 em diante o reconhecimento de passivos contingentes seria, no máximo, equivalente aos valores anuais das privatizações totais, isso de fato não ocorreu. Apesar de nos anos de 1997, 2000, 2006, 2007 e 2008, as receitas das privatizações terem sido superiores aos reconhecimentos das dívidas dos passivos contingentes, nos demais anos do período em análise as dívidas dos passivos contingentes foram superiores às receitas das privatizações.

\subsection{3 - A variação cambial}

Nesta subseção será apresentada a participação da variação da taxa de câmbio na variação da DLSP/PIB, no período de 1996 a 2008.

A variação cambial interfere na dívida pública porque o setor público possui além da dívida externa, dívida interna indexada ao câmbio. Ambas aumentam quando a confiança na moeda do país diminui. Quando ocorre uma desvalorização na taxa de câmbio, o valor da dívida pública externa aumenta porque essa dívida convertida em real passa a ser maior, devido ao dólar ficar mais caro em relação à moeda doméstica. Ao contrário, quando ocorre valorização na taxa de câmbio, a dívida externa tende a diminuir, pois, com o real mais valorizado pode-se comprar mais dólares com a mesma quantidade de reais (CASTRO, 2007).

Com relação à dívida pública indexada à variação cambial, quando ocorre uma desvalorização na taxa de câmbio, o setor público paga, além de outros indexadores, a variação do câmbio. Essa contribuição para a variação da dívida 
depende do montante da dívida pública que esteja indexada o câmbio (CASTRO, 2007).

Em linhas gerais, os sistemas cambiais se classificam em (GRYZER, 2006):

- Taxa de Câmbio Flexível ou Flutuante - o valor é determinado livremente no mercado de divisas, através da interação das forças da oferta e demanda;

- Taxa de Câmbio Fixa - o valor é fixado pelo Banco Central, que se compromete a comprar e vender qualquer quantidade de divisas a esta taxa; e

- Sistema de Bandas Cambiais - O Banco Central define um intervalo com limite mínimo e máximo (banda) para flutuação das taxas de câmbio. Se a taxa ameaçar romper o limite mínimo, o Banco Central compra divisas para aumentar a cotação; se o limite máximo for ameaçado, o Banco Central vende divisas, para baixar a cotação.

Durante o Plano Real, estes sistemas foram adotados da seguinte forma:

- Câmbio Flutuante - julho de 1994 a março de 1995;

- Câmbio Fixo com Sistema de Bandas - março de 1995 a janeiro de 1999; e

- Câmbio Flutuante - janeiro de 1999 até os dias atuais.

Segundo Goldfajn e Paula:

Uma desvalorização cambial acima da inflação aumenta o serviço real da
dívida pública. Para amortecer os "ruídos" gerados pela variação do câmbio
real, seria preferível reduzir a dívida indexada ao câmbio à medida em que
sua volatilidade aumenta (diminuindo a elasticidade da dívida com respeito
ao câmbio). Um corolário deste raciocínio é a redução da parcela da dívida
em dólar sob o regime de câmbio flutuante, imunizando o orçamento
governamental de maiores variabilidades cambiais (GOLDFAJN; PAULA,
1999, p. 5).
Se os gastos do governo são positivamente correlacionados com a moeda
estrangeira, é recomendável a diminuição da dívida em moeda estrangeira
e aumento da dívida nominal, de forma a imunizar o orçamento de
variações imprevistas no câmbio (GOLDFAJN; PAULA, 1999, p. 5).

Desde a implantação do Plano Real, a manutenção da taxa de câmbio sobrevalorizada agravava a situação de dependência de entrada de capitais, uma vez que as divisas eram necessárias para equilibrar as contas externas. A entrada de divisas motivada pelos juros altos causou dois problemas: aumento da dívida pública e aumento dos gastos do governo. 
Em 1996 a política cambial foi caracterizada por minidesvalorizações, como incentivo às exportações e inibição às importações, pois o déficit na balança comercial havia atingido cerca de US\$ 5 bilhões.

Em fevereiro de 1997, o Banco central estipulou novos valores para a banda cambial, na tentativa de melhorar a balança comercial. Nessa época o Brasil acumulava reservas internacionais desde abril de 1995, após superação da crise mexicana, que ultrapassava a US\$ 60 bilhões. Porém, com a crise da Ásia, a economia brasileira voltou a apresentar vulnerabilidade em outubro de 1997, com perda de reservas. Para manter as reservas, o governo voltou a elevar a taxa de juros, fazendo com que as reservas internacionais voltassem a crescer em janeiro de 1998, chegando a US\$ 74 bilhões.

Em decorrência de problemas tais como: a instabilidade econômica mundial, a eleição para presidente e governadores, e o câmbio ter ultrapassado o limite superior das bandas em dezembro de $1998^{1}$, como era esperado, em 15 de janeiro de 1999, o Banco Central anunciou que não interviria mais na cotação do câmbio, e, três dias depois, foi formalizado o novo regime cambial de livre flutuação do câmbio. O câmbio flutuante tenderia a diminuir os déficits na balança comercial e incentivaria a entrada de divisas através das exportações, enquanto a inflação estaria sob controle devido aos juros altos, provocando desestímulo do consumo e da produção. Dessa forma, ocorreu uma inversão das funções das políticas cambial e monetária. Nesse mesmo ano, a flutuação do câmbio possibilitou melhora na balança comercial, queda dos juros e desvalorização natural da taxa de câmbio (GRYZER, 2006).

A taxa de câmbio apresentou elevação a partir da adoção do regime de câmbio flutuante em janeiro de 1999, com destaque para o período de maior oscilação entre o segundo semestre de 2002 e o primeiro semestre de 2003, em conseqüência do quadro político vivido pelo Brasil naquele período. A partir do segundo semestre de 2003 até 2008, o real passou a apresentar bons resultados na valorização perante o dólar.

Na tabela 3, são apresentados os impactos da variação cambial na evolução da relação da DLSP/PIB, no período de 1996 a 2008.

\footnotetext{
1 Por ter ocorrido fortes reduções nas reservas internacionais, chegando a apenas US $\$ 36,14$ bilhões em janeiro de 1999.
} 
Tabela 3

Impactos da variação cambial na variação DLSP/PIB - 1996 a 2008

(R\$ milhões)

\begin{tabular}{r|r|r|r}
\hline Ano (1) & \multicolumn{1}{|c|}{$\begin{array}{c}\text { Ajuste } \\
\text { cambial }\end{array}$} & $\begin{array}{c}\text { PIB acum. } \\
\text { doze meses } \\
\text { - valorizado }\end{array}$ & $\begin{array}{c}\text { Impacto } \\
\text { Ajuste } \\
\text { cambial na } \\
\text { DLSP/PIB }\end{array}$ \\
\hline 1996 & 1.530 & 876.300 & 0,17 \\
\hline 1997 & 4.114 & 968.874 & 0,42 \\
\hline 1998 & 6.859 & 990.978 & 0,69 \\
\hline 1999 & 69.384 & 1.159 .973 & 5,98 \\
\hline 2000 & 18.344 & 1.236 .538 & 1,48 \\
\hline 2001 & 30.840 & 1.364 .379 & 2,26 \\
\hline 2002 & 147.225 & 1.745 .822 & 8,43 \\
\hline 2003 & -64.307 & 1.744 .123 & $-3,69$ \\
\hline 2004 & -16.193 & 2.036 .783 & $-0,80$ \\
\hline 2005 & -18.202 & 2.157 .435 & $-0,84$ \\
\hline 2006 & -4.881 & 2.424 .641 & $-0,20$ \\
\hline 2007 & 29.268 & 2.736 .836 & 1,07 \\
\hline 2008 & -98.217 & 2.986 .154 & $-3,29$ \\
\hline
\end{tabular}

Fonte: BACEN

Elaboração do autor

(1) Devido à falta de disponibilidade das informações da variação cambial em 1995, são apresentados os dados a partir de 1996.

Para melhor análise do impacto da variação cambial na relação DLSP/PIB, pode-se dividir o período considerado em dois períodos menores. No primeiro período, de 1996 a 2002, a desvalorização cambial contribuiu para elevar a relação DLSP/PIB em todos os anos, com picos bastante acentuados em 1999, com contribuição de 5,98\% do PIB, e 2002, com contribuição de $8,43 \%$ do PIB. Já no segundo período, de 2003 a 2008, a valorização cambial contribuiu para reduzir a relação DLSP/PIB em quase todos os anos, com destaque para 2003, com contribuição 3,69\% do PIB, e 2008 com contribuição de 3,29\% do PIB. Neste último período, apenas em 2007 ocorreu desvalorização cambial, que contribuiu com $1,07 \%$ do PIB para elevação da relação DLSP/PIB. 
Em 2003, ano com maior valor da relação DLSP/PIB $(52,4 \%)$ no período analisado, a valorização cambial contribuiu com 3,69\% do PIB para reduzir a relação DLSP/PIB. Isto significa que o fator que contribuiu fortemente para esse valor da relação DLSP/PIB ainda será identificado mais adiante, haja vista que nenhum dos fatores analisados até aqui (privatizações, passivos contingentes e variação cambial) foi responsável por esse valor tão elevado.

\subsection{4 - Os juros nominais}

Nesta subseção será apresentada a contribuição dos juros nominais para 0 aumento da relação DLSP/PIB, no período de 1995 a 2008.

A política monetária oscilou durante o Plano Real, elevando as restrições durante as crises externas. A opção por uma política monetária restritiva resultou na prática de juros altos, restrição de crédito, elevação das taxas dos depósitos compulsórios e abertura das operações de mercado aberto para a venda de títulos públicos (GRYZER, 2006).

Foram mantidas taxas de juros internas muito elevadas, em comparação com as taxas externas, para conter a demanda e atrair capitais externos. Com isso, pretendia-se esterilizar a moeda nacional emitida, que era facilmente trocada por moeda estrangeira, e aumentar as reservas no início do plano. Tais taxas de juros a partir de 1995 contribuíram para o aumento da dívida pública interna e externa, e influenciaram negativamente a economia através da redução dos níveis de investimentos, elevação da inadimplência e aumento do custo das empresas endividadas.

Devido à crise do México em dezembro de 1994, essas taxas sofreram uma forte elevação em abril de 1995, com o objetivo de barrar a saída de capitais. Em agosto de 1995, foi iniciado um processo de redução que não durou muito, pois, no segundo semestre de 1997, com a crise Asiática, os juros voltaram a subir, o que ocorreu novamente em agosto de 1998 com a crise da Rússia, permanecendo elevados até 1999.

Ao longo do ano 2000 a política monetária foi submetida a algumas incertezas geradas pelo mercado externo, tais como aumento no preço internacional do petróleo e dificuldades enfrentadas pela economia Argentina, que afetaram também 
- Brasil. A estratégia usada pelo governo para minimizar essas incertezas foi manter a taxa de juros elevada. Contudo, a Selic apresentou queda ao longo do ano.

Em 2001, com o objetivo de proporcionar o aumento da oferta de moeda estrangeira no país, o Copom optou por elevar novamente a taxa Selic. Para desestimular a retenção de moeda estrangeira por parte dos agentes internos, 0 governo passou a cobrar um compulsório de $10 \%$ sobre os depósitos a prazo.

A partir de meados de 2002, devido ao aumento da preferência pela liquidez na economia, a condução da política monetária foi caracterizada por postura conservadora. O baixo crescimento mundial e as incertezas quanto à futura política econômica interna no período pré-eleitoral geraram condições para movimentos especulativos. Assim, os recolhimentos compulsórios sobre depósitos a prazo foram elevados e ocorreu também um novo aumento da taxa Selic.

Em 2003, devido ao quadro de incertezas e turbulências causadas no mercado financeiro em função das eleições de 2002, a política monetária foi ajustada para que as metas de inflação fossem cumpridas. Utilizando a taxa de juros como principal instrumento de política monetária para reverter o crescimento da inflação, a taxa Selic sofreu mais uma pequena elevação durante o ano.

A situação foi revertida a partir de 2004 e se sustentou até 2008, com a condução da política monetária de forma a assegurar crescimento sustentado do produto, reduzindo a taxa de juros ao longo do período, com exceção de 2005, ano em que a taxa de juros sofreu oscilações ao longo do ano, resultando numa pequena elevação.

Na tabela 4, são apresentados os impactos dos juros nominais na evolução da DLSP, no período de 1995 a 2008. 
Tabela 4

Impactos dos juros nominais na variação DLSP/PIB - 1995 a 2008

(R\$ milhões)

\begin{tabular}{r|r|r|r}
\hline Ano & \multicolumn{1}{|c|}{$\begin{array}{c}\text { Juros } \\
\text { nominais }\end{array}$} & $\begin{array}{r}\text { PIB acum. } \\
\text { doze meses } \\
\text { - valorizado }\end{array}$ & $\begin{array}{c}\text { Impacto } \\
\text { Juros nominais } \\
\text { na DLSP/PIB }\end{array}$ \\
\hline 1995 & 51.065 & 745.091 & 6,85 \\
\hline 1996 & 44.229 & 876.300 & 5,05 \\
\hline 1997 & 43.317 & 968.874 & 4,47 \\
\hline 1998 & 68.335 & 990.978 & 6,90 \\
\hline 1999 & 87.372 & 1.159 .973 & 7,53 \\
\hline 2000 & 77.963 & 1.236 .538 & 6,30 \\
\hline 2001 & 86.444 & 1.364 .379 & 6,34 \\
\hline 2002 & 114.004 & 1.745 .822 & 6,53 \\
\hline 2003 & 145.210 & 1.744 .123 & 8,33 \\
\hline 2004 & 128.256 & 2.036 .783 & 6,30 \\
\hline 2005 & 157.146 & 2.157 .435 & 7,28 \\
\hline 2006 & 160.027 & 2.424 .641 & 6,60 \\
\hline 2007 & 159.532 & 2.736 .836 & 5,83 \\
\hline 2008 & 162.344 & 2.986 .154 & 5,44 \\
\hline
\end{tabular}

Fonte: BACEN

Elaboração do autor

No período analisado, constata-se forte contribuição dos juros nominais na elevação da relação DLSP/PIB. Em 2003, ano com o maior valor da relação DLSP/PIB (52,4\%), foi também o ano em que os juros nominais mais contribuíram (8,33\%) para aumentar essa relação. Em 1997, ano com o menor valor percentual dos juros nominais no período, os juros nominais contribuíram com 4,47\% do PIB para aumentar a relação DLSP/PIB, demonstrando que, mesmo o menor valor percentual dos juros nominais do período analisado representou um impacto muito forte na elevação da relação DLSP/PIB. 


\subsection{5 - O resultado primário}

Nesta subseção será analisada a participação do resultado primário na variação da DLSP/PIB, no período de 1995 a 2008.

Com a implantação do Plano Real, a política fiscal se caracterizou por um aumento da tributação. Foram criados alguns impostos e aumentado outros, com o objetivo de aumentar a arrecadação total. No período analisado, o resultado primário apresentou comportamento bem diferenciado em dois períodos menores.

No primeiro período, que compreende os anos de 1995 a 1998, o resultado primário foi muito baixo, inclusive apresentou déficit em 1996 e 1997, sendo as causas desse fraco desempenho fiscal explicadas por Castro (2007):

I. Forte queda da inflação, que enfraqueceu um efeito muito utilizado em períodos de inflação alta: atraso nos pagamentos não indexados, desvalorizando-os em termos reais, como os salários dos servidores e o pagamento de fornecedores;

II. Aumento acentuado dos gastos com a seguridade social. Em 1994 esses gastos representavam $4,9 \%$ do PIB, elevando-se para $8,2 \%$ do PIB em 1998; e

III. Deterioração do resultado de estados e municípios, causada principalmente pela expansão dos gastos com pessoal, acima de $60 \%$ da receita corrente líquida na maior parte dos estados.

Já no segundo período, que compreende os anos de 1999 a 2008, o superávit primário elevou-se significativamente, justificado por Castro (2007):

i. Aumento do aperto da política fiscal, com superávit primário superior a $2,7 \%$ do PIB em todos os anos;

ii. Aumento da carga tributária;

iii. Federalização de quase todas as dívidas estaduais e várias dívidas municipais a partir de 1997, cujo instrumento legal foi a Lei 9.496/97. Essa federalização da dívida estabeleceu a contrapartida de pagamentos na forma de uma Tabela Price, com prestações mensais no período de 30 anos e juros reais de $6 \%$ ao ano, limitado a $13 \%$ da receita líquida;

iv. Aumento da austeridade fiscal nas três esferas de governo, com a aprovação da LRF em 2000. Em razão da proibição de refinanciamento, contida nessa lei, os prováveis credores que se 
dispusessem a financiar algum ente da federação estariam cientes de que, a partir de então, o Tesouro Nacional não mais socorreria entes em dificuldades, estabelecendo-se assim uma disciplina de mercado na aprovação de novos contratos;

v. Elevação dos preços internacionais do petróleo em 1999, que afetou de forma positiva a Petrobrás, gerando um aumento acentuado nas suas receitas, não acompanhado na mesma magnitude pelo aumento nas suas despesas, o que proporcionou evolução significativa no superávit primário nas empresas estatais federais como um todo; e

vi. Melhoria nos resultados das empresas estatais estaduais e municipais, a partir de 1999, causada pelas mudanças institucionais e pelo padrão de comportamento das autoridades estaduais e municipais, além das privatizações. As privatizações beneficiaram as estatísticas fiscais através do desaparecimento das estatísticas de empresas deficitárias que foram vendidas e melhora na gestão das empresas estatais remanescentes, num contexto mais competitivo.

Vale ressaltar que, a partir de 1999, com a assinatura do acordo com o FMI, a política fiscal nos três níveis de governo e nas empresas estatais experimentou uma mudança drástica, com o país passando a operar sob um regime de restrição orçamentária efetiva (CASTRO, 2007).

Apesar de não estar sendo analisado neste trabalho, deve-se observar que o resultado da previdência social faz parte do resultado primário do governo federal, e, a partir de 1998, a previdência social tem apresentado déficts crescentes, o que contribui para diminuir o superávit primário.

$\mathrm{Na}$ tabela 5, são apresentados os impactos do resultado primário na evolução da relação DLSP/PIB, no período de 1995 a 2008. 
Tabela 5

Impactos do resultado primário na variação DLSP/PIB - 1995 a 2008

(R\$ milhões)

\begin{tabular}{r|r|r|r}
\hline Ano & $\begin{array}{r}\text { Resultado } \\
\text { Primário }\end{array}$ & $\begin{array}{r}\text { PIB acum. } \\
\text { doze meses } \\
\text { - valorizado }\end{array}$ & $\begin{array}{r}\text { Impacto } \\
\text { Res. Primário } \\
\text { na DLSP/PIB }\end{array}$ \\
\hline 1995 & 2.415 & 745.091 & 0,32 \\
\hline 1996 & -740 & 876.300 & $-0,08$ \\
\hline 1997 & -8.310 & 968.874 & $-0,86$ \\
\hline 1998 & 106 & 990.978 & 0,01 \\
\hline 1999 & 31.087 & 1.159 .973 & 2,68 \\
\hline 2000 & 38.157 & 1.236 .538 & 3,09 \\
\hline 2001 & 43.656 & 1.364 .379 & 3,20 \\
\hline 2002 & 52.390 & 1.745 .822 & 3,00 \\
\hline 2003 & 66.173 & 1.744 .123 & 3,79 \\
\hline 2004 & 81.112 & 2.036 .783 & 3,98 \\
\hline 2005 & 93.505 & 2.157 .435 & 4,33 \\
\hline 2006 & 90.144 & 2.424 .641 & 3,72 \\
\hline 2007 & 101.606 & 2.736 .836 & 3,71 \\
\hline 2008 & 118.037 & 2.986 .154 & 3,95 \\
\hline
\end{tabular}

Fonte: BACEN

Elaboração do autor

No período analisado, constata-se que, mesmo com a forte contribuição do superávit primário de 1999 a 2003 para redução da dívida pública, a relação DLSP/PIB continuou crescente até 2003, impulsionada principalmente pelos juros nominais. De 2004 a 2008, a queda acentuada na relação DLSP/PIB pode ser creditada, em boa parte, aos ótimos valores de superávit primário obtidos nesse período.

\subsection{6 - O crescimento econômico}

Nesta subseção será analisada a contribuição do crescimento da economia na variação da relação DLSP/PIB, no período de 1995 a 2008. 
A forma mais clássica e tradicional de se medir o crescimento econômico de um país é medir o crescimento de seu Produto Interno Bruto (PIB). O PIB representa a soma (em valores monetários) de todos os bens e serviços finais produzidos num país, durante um período determinado, geralmente um ano.

O fator que determina o crescimento da economia de um país é a taxa de variação do PIB.

Em relação ao período analisado, no segundo semestre de 1997, quando a economia apresentava mostras de crescimento razoável, aconteceu a crise asiática, e o governo teve que aumentar as taxas de juros para ajustar a economia brasileira à situação econômica internacional.

Diante da crise da Rússia, em meados de 1998, que provocou recessão na maioria dos países em desenvolvimento, o PIB brasileiro apresentou um crescimento quase insignificante.

Em 1999, a crise ocorreu na própria economia brasileira que, em razão de um ataque especulativo, o país teve que desvalorizar o Real e deixá-lo flutuar livremente. Nessa ocasião, o governo brasileiro aumentou as taxas de juros, no intuito de atrair mais dólares para o mercado brasileiro e também para conter o aumento no nível dos preços provocado pelas grandes desvalorizações do Real frente ao Dólar desde que foi determinada a livre flutuação do Real no início do ano (CASTRO, 2007).

No ano 2000 a economia brasileira caminhava no sentido de obter bons resultados no crescimento econômico, com crescimento do PIB em 4,3\%. Porém, em 2001 ocorreram dois fatores que interferiram negativamente nesse crescimento: a crise energética e o atentado de 11 de setembro de 2001, nos Estados Unidos, contribuindo para que o PIB brasileiro crescesse apenas 1,3\% nesse ano.

No período de 2004 a 2008, o PIB apresentou excelentes crescimentos, com destaque para os anos 2004 e 2007, quando o crescimento chegou a 5,7\%, contribuindo fortemente para a redução da relação DLSP/PIB, ocorrida nesse período.

O Gráfico 2 demonstra os valores relativos às taxas de crescimento do PIB Brasil no período de 1995 a 2008. 


\section{Gráfico 2}

Crescimento do PIB Brasil - 1995 a 2008

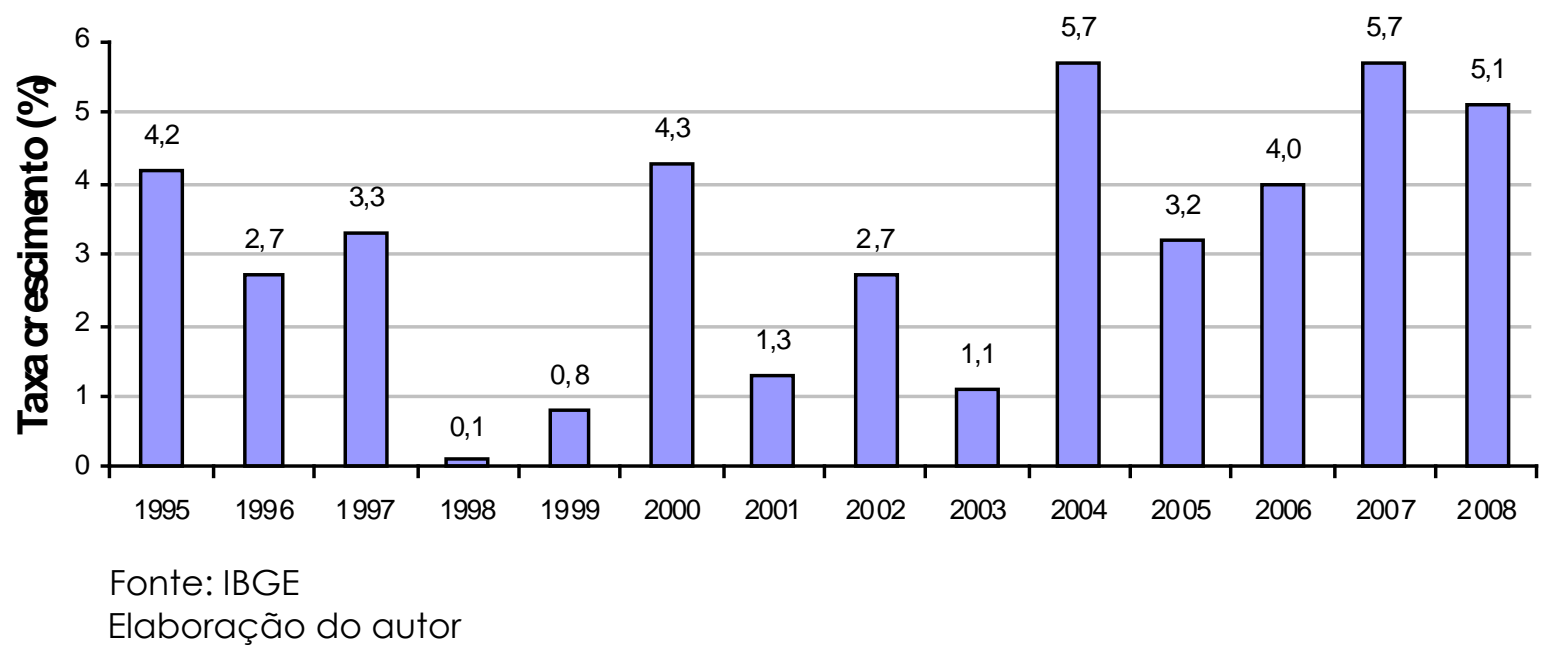

No período analisado, constata-se forte contribuição do crescimento do PIB na redução da relação DLSP/PIB ocorrida nos anos de 2004 a 2008.

Em 2003, ano com maior valor da relação DLSP/PIB $(52,4 \%)$ no período analisado, o crescimento do PIB foi de apenas 1,1\%, contribuindo muito pouco para neutralizar os impactos dos juros no aumento ocorrido na relação DLSP/PIB, nesse ano.

O Gráfico 3 demonstra o efeito do crescimento econômico sobre a DLSP no período de 1995 a 2008. 


\section{Gráfico 3}

Efeito do crescimento do PIB sobre a DLSP - 1996 a 2008

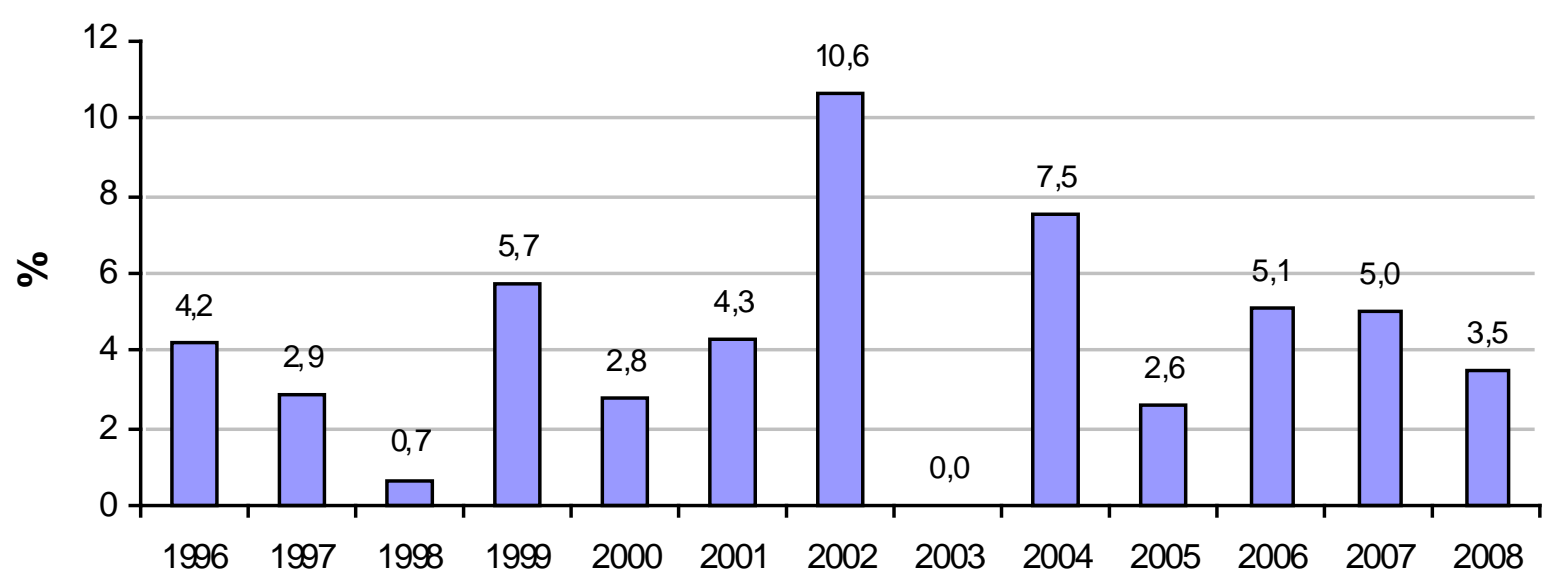

Fonte: BACEN

Elaboração do autor

Devido à falta de disponibilidade da informação do efeito do crescimento do PIB sobre a DLSP em 1995, são apresentados os dados a partir de 1996.

Conforme demonstrado no gráfico 3, o efeito do crescimento do PIB sobre a DLSP foi maior nos anos de 2002 (10,6\%) e 2004 (7,5\%). Em 2003, ano com maior valor da relação DLSP/PIB $(52,4 \%)$ no período analisado, o efeito do crescimento do PIB sobre a DLSP foi de 0,0\%, o que justifica em parte esse valor tão elevado da relação DLSP/PIB, nesse ano. 


\section{3 - METODOLOGIA}

O estudo trata-se de uma pesquisa empírica documental, de natureza quantitativa e qualitativa, de caráter exploratório, envolvendo análise de dados, com a finalidade de avaliar a contribuição dos fatores condicionantes na evolução da dívida pública brasileira.

Neste trabalho realizou-se também pesquisa bibliográfica com a finalidade de fundamentar a parte conceitual (SILVA; MENEZES, 2001).

\section{1 - Participantes da pesquisa}

Os dados apresentados e analisados neste trabalho foram obtidos de fontes secundárias, através de consultas a relatórios, boletins e outras publicações, disponíveis nos sites do BACEN, do IPEA e do IBGE.

Neste trabalho, utilizou-se basicamente os dados relativos aos fatores condicionantes da DLSP, a evolução da relação DLSP/PIB e a taxa de crescimento do PIB.

Os dados são então compostos pelas privatizações e concessões, passivos contingentes, variação cambial, juros nominais, resultado primário, crescimento do PIB, dívida líquida do setor público e PIB valorizado.

Para avaliar o crescimento econômico, utilizou-se a taxa de crescimento do PIB, disponibilizada pelo IBGE.

Para avaliar a evolução da DLSP, utilizou-se os dados relativos aos fatores condicionantes, disponibilizados pelo BACEN.

\section{2 - Instrumentos e Procedimentos}

A análise quantitativa dos dados foi feita através da utilização de recursos tais como gráficos e tabelas, de forma a demonstrar a contribuição dos fatores que conduziram à variação da DLSP, bem como a atuação do Estado brasileiro na gestão e sustentabilidade da dívida pública, no período considerado. 


\section{4 - ANÁLISE DA EVOLUÇÃO DA DLSP E IMPACTOS DOS FATORES CONDICIONANTES}

Neste capítulo, será inicialmente feita uma breve discussão sobre a mudança no perfil da dívida pública brasileira, com elevação da dívida interna e redução da dívida externa, ocorrida no período em análise. Em seguida, serão discutidos os dados sobre a contribuição dos fatores condicionantes na variação da DSLP em relação ao $\mathrm{PIB}$, ao longo desse período. Essa discussão será, na maioria das vezes, tratada em dois períodos menores, considerando o pico da relação DLSP/PIB em 2003, que foi de $52,4 \%$.

Ao longo do período analisado, o perfil da dívida pública brasileira foi se modificando, devido à política econômica adotada pelo governo. A partir de 2003 ocorreu um aumento no fluxo de divisas para o Brasil, elevando as reservas internacionais e contribuindo para a melhora dos principais indicadores de solvência externa. Dessa forma, a dívida interna tomou o lugar da dívida externa, passando a ser o principal problema da economia brasileira.

A dívida externa líquida (passivos externos menos reservas internacionais) caiu de $24,6 \%$ do PIB (58,5\% da dívida líquida total) em janeiro de 1991 para 2,3\% do PIB (5,0\% da dívida líquida total) em dezembro de 2005. No mesmo período, a dívida interna liquida passou de $17,4 \%$ do PIB (41,5\% da dívida líquida total) para $44,1 \%$ do PIB $(95,0 \%$ da dívida líquida total), fazendo com que a dívida líquida passasse a ser quase toda composta por dívida interna.

A partir de 2006, as reservas internacionais foram superiores aos passivos externos, contribuindo de forma significativa para redução da dívida líquida externa do setor público. Entretanto, cabe destacar que o aumento das reservas internacionais foi compensado pela dívida do Banco Central no mercado interno, resultando em efeito nulo sobre o estoque da DLSP.

A DLSP passou de 208.460,27 milhões de reais em 1995 para 1.069.579,28 milhões de reais em 2008, representando um aumento de 480,8\% em termos nominais. Nesse mesmo período, essa dívida em relação ao PIB passou de $28,0 \%$ para 35,8\%, sendo que a dívida interna foi responsável por 22,9\% em 1995 e 49,9\% em 2008 e, a dívida externa foi responsável por 5,1\% em 1995 e uma redução de $14,1 \%$ em 2008. Contudo, é necessário que essa análise seja feita com mais 
detalhes ao longo desse período, haja vista que a relação DLSP/PIB teve uma forte elevação de 1995 a 2003, passando de 28,0\% para 52,4\%, e, em seguida, uma redução acentuada, passando dos 52,4\% em 2003 para 35,8\% em 2008.

O Gráfico 4 demonstra a mudança no perfil da dívida pública brasileira, com redução da dívida líquida externa e elevação da dívida líquida interna, no período analisado.

\section{Gráfico 4}

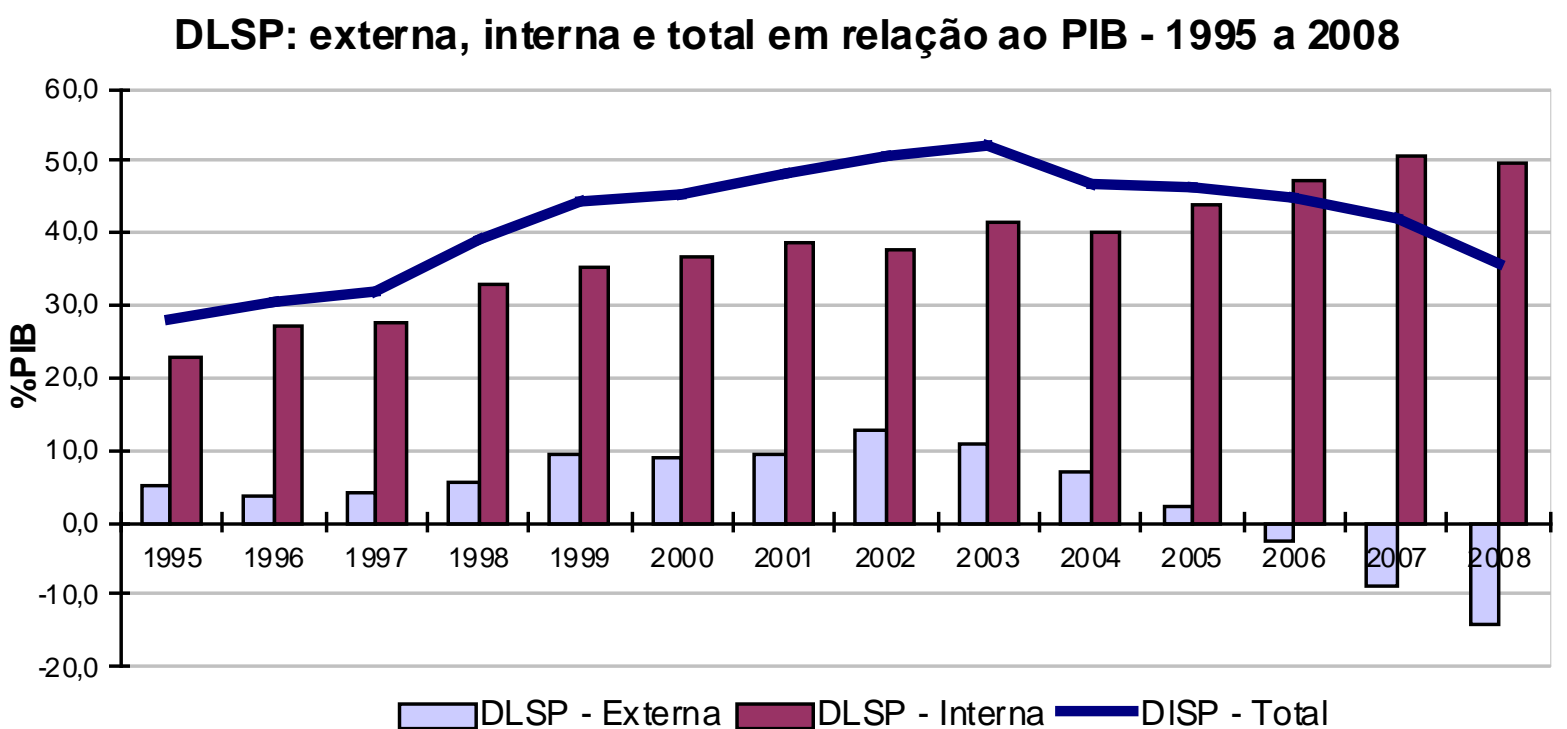

Fonte: IPEADATA

Dados referentes ao mês de dezembro de cada ano Elaboração do autor

Quanto à contribuição das privatizações e concessões, realizadas no período analisado, para redução da dívida pública e, conseqüentemente manter a estabilidade da relação DLSP/PIB, o valor total foi de $R \$ 69.517$ milhões, concentrada, principalmente, no período 1997 a 2000.

O reconhecimento de dívidas relativas aos passivos contingentes, por parte do governo, contribuiu consideravelmente para o aumento da DLSP. A contribuição total dessas dívidas, no período analisado, foi de $\mathrm{R} \$ 102.151$ milhões, concentrada, principalmente, no período de 1995 a 2002. Porém, nos anos seguintes, quando a relação DLSP/PIB foi decrescente, a contribuição dos passivos contingentes foi quase insignificante, não representando um fator determinante para essa redução. Quanto à meta informal de que as receitas obtidas com as privatizações compensaria as despesas com os passivos contingentes, verifica-se que isso não 
ocorreu, pois as despesas com os passivos contingentes foram superiores às receitas com privatizações em $\mathrm{R} \$ 32.634$ milhões no período de 1995 a 2008.

A variação cambial contribuiu significativamente para a variação da relação DLSP/PIB, no período em análise, tanto para elevá-la quanto para reduzi-la. Observa-se que de 1996 a 2002 a variação cambial contribuiu para aumentar a dívida pública, principalmente de 1999 a 2002, quando essa contribuição proporcionou um grande aumento na dívida pública, devido às desvalorizações do real frente ao dólar, ocorridas nesses anos, e ao aumento da dívida pública interna indexada à taxa de câmbio (CASTRO, 2007). Em 2003, mesmo com a grande contribuição da variação cambial para redução da dívida pública, ocorreu o valor mais alto da relação DLSP/PIB do período analisado. No período de 2004 a 2006 a variação cambial contribuiu para diminuir a dívida pública com impacto bem menor do que a contribuição para aumentá-la ocorrida no período anterior. As razões disso foram que a magnitude das valorizações foi menor do que a das desvalorizações, e a dívida pública líquida indexada à variação cambial era também menor do que a do período anterior. Em 2007, a variação cambial teve forte contribuição para aumentar a dívida pública, porém a relação DLSP/PIB se manteve decrescente. Já em 2008, a variação cambial contribuiu fortemente para redução da dívida pública e conseqüentemente para redução da relação da DLSP/PIB. Semelhante ao que ocorreu com a contribuição dos passivos contingentes, no período de 1996 a 2002, a variação cambial contribuiu com um total de $R \$ 278.296$ milhões para elevação da relação DLSP/PIB. Já no período seguinte, 2003 a 2008, a variação cambial contribuiu com um total de $R \$ 172.532$ milhões para redução na relação DLSP/PIB.

Os juros nominais representaram o principal fator responsável para o crescimento da dívida pública no período de 1995 a 2008, contribuindo com um total de $R \$ 1.485 .244$ milhões. No Gráfico 5 é feita uma demonstração da evolução da relação DLSP/PIB com e sem o impacto dos juros nominais. Constata-se que, embora os juros nominais tenham representado o fator que mais contribuiu para 0 crescimento da dívida pública, e, conseqüentemente, da relação DLSP/PIB, não foram eles os responsáveis pela variação da relação DLSP/PIB, pois, independentemente dos juros nominais, a relação DLSP/PIB manteve as mesmas tendências no período analisado, crescente até 2003 e decrescente a partir de 2004. 


\section{Gráfico 5}

Evolução DLSP/PIB com e sem Juros nominais - 1995 a 2008

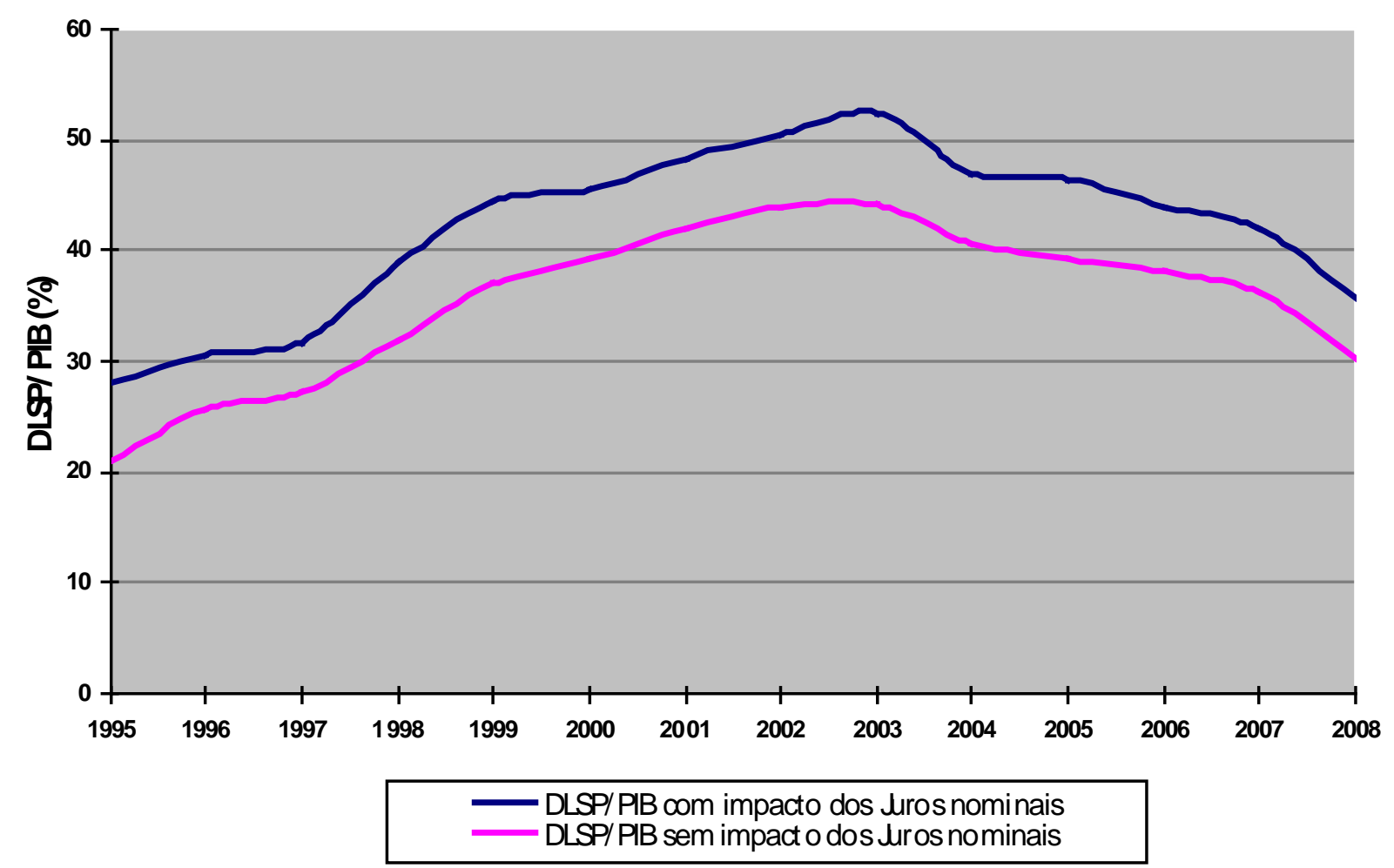

Fonte: BACEN

Elaboração do autor

O resultado primário contribuiu muito para conter o crescimento da dívida pública brasileira no período de 1995 a 2008, contribuindo com um total de $R \$$ 709.338 milhões. A partir de 1998 esse resultado passou a ser superavitário e crescente. A partir de 1999 até 2008, esse resultado contribuiu fortemente para impedir um crescimento explosivo da dívida pública. No entanto, para obtenção desse resultado, a sociedade brasileira foi onerada com um aumento acentuado da carga tributária, ao longo do período analisado. Vale observar que esse superávit primário poderia ter sido bem melhor se a previdência social não tivesse apresentado déficits crescentes durante todo o período, pois, parte desse superávit foi destinado ao pagamento do déficit da previdência social (CASTRO, 2007). No período de 1995 a 2003, mesmo com a contribuição do superávit primário a partir de 1998 para reduzir a dívida pública, a relação DLSP/PIB se manteve crescente, devido à contribuição de outros fatores, principalmente a variação cambial, os passivos contingentes e os juros nominais. No período de 2004 a 2008, além de contribuir para redução da dívida pública, os valores do superávit primário, juntamente com a contribuição da valorização cambial, foram fortes o suficiente para 
compensar os valores contrários de outros fatores e gerar uma redução significativa na relação DLSP/PIB.

O fraco crescimento econômico, no período de 1995 a 2003, contribuiu para que a relação DLSP/PIB mantivesse uma tendência ascendente nesse período. No período seguinte, de 2004 a 2008, o PIB apresentou forte crescimento, sendo um dos principais fatores que contribuíram para que a relação DLSP/PIB mantivesse tendência descendente nesse período.

Conforme já apresentado anteriormente, no período analisado a relação DLSP/PIB cresceu nos primeiros anos, passando de 28,0\% em 1995 para 52,4\% em 2003 e, decresceu nos anos seguintes, chegando a 35,8\% em 2008. Considerando a contribuição conjunta dos fatores condicionantes, pode-se constatar que, a tendência crescente da relação DLSP/PIB no primeiro período deveu-se, principalmente, a: forte contribuição dos juros nominais, concentração dos passivos contingentes e desvalorização cambial. No segundo período, a tendência decrescente da relação DLSP/PIB deveu-se, principalmente, a: excelentes superávits primários, valorização cambial e bons resultados do crescimento do PIB. No Gráfico 6 é feita uma demonstração da evolução da relação DLSP/PIB com e sem os impactos da contribuição dos juros nominais, da variação cambial e do resultado primário, que, dos fatores analisados, foram os mais significativos no período de 1996 a 2008. 
Gráfico 6

Evolução DLSP/ PBBcom e sem juros, câmbio e primário 1996 a 2008

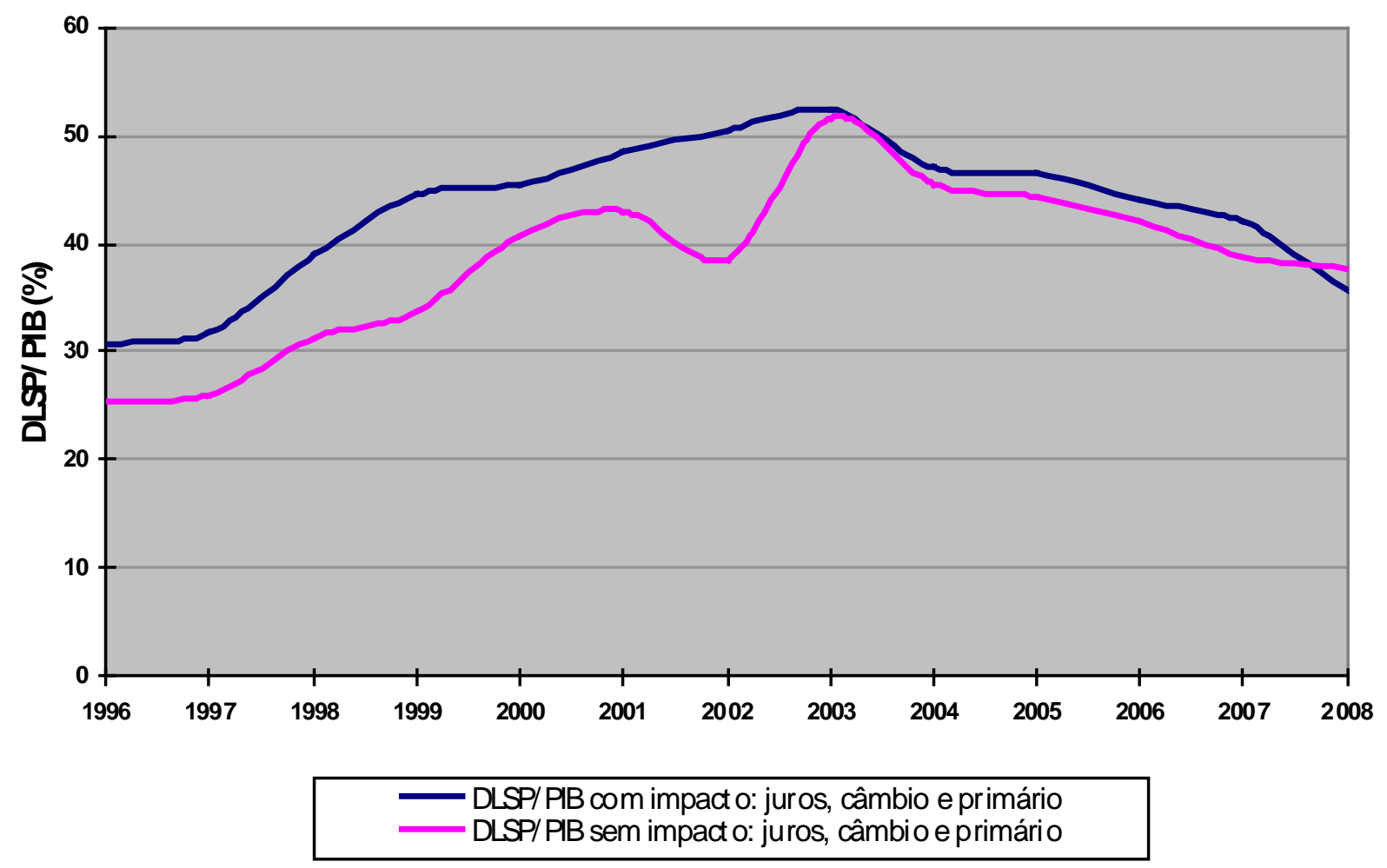

Fonte: BACEN

Elaboração do autor

No período analisado, constata-se que independentemente da contribuição dos juros nominais, da variação cambial e do resultado primário, a tendência da relação DLSP/PIB manteria uma tendência crescente nos anos de 1996 a 2003. Isto devido ao fraco crescimento do PIB nesse período. Nos anos seguintes, de 2004 a 2008, a relação DLSP/PIB manteve uma tendência decrescente, devido aos bons resultados obtidos no crescimento do PIB, à valorização cambial e, principalmente aos superávits primários crescente. Os juros nominais, embora tenham mantido a forte contribuição para a elevação da dívida pública, não tiveram impacto significativo na tendência da relação DLSP/PIB nessa segunda parte do período, pois foram compensados pelos bons resultados dos outros três fatores. 


\section{5 - CONCLUSÃO}

Nesta monografia foram feitas as descrições, apresentados os dados e, discutidas e analisadas as participações dos fatores que contribuíram para a evolução da dívida pública brasileira e, conseqüentemente, para a variação da relação DLSP/PIB, no período de 1995 a 2008.

Apesar de as privatizações no Brasil terem ocorrido em três fases distintas, nesta monografia trabalhamos apenas com a terceira fase, com as privatizações e concessões iniciadas em 1995, com a participação dos estados e das empresas dos setores de telecomunicações, mineração e elétrico. Nesta fase, o processo de privatizações e concessões proporcionou leves ganhos fiscais. Os anos de 1997 e 1998 foram os que apresentaram a maior contribuição de todo o período analisado.

As dívidas referentes aos passivos contingentes, reconhecidas pelo setor público no período de 1996 a 2008, contribuíram para a elevação da relação DLSP/PIB, especialmente na primeira parte do período, quando essa relação apresentou tendência crescente, de 1996 a 2003. Porém, essas medidas contribuíram para solucionar diversos problemas que vinham se arrastando por muito tempo e que, se não tivessem sido solucionados, elevariam ainda mais os seus custos financeiros.

A taxa de câmbio apresentou leve crescimento até 1998, com uma contribuição quase insignificante no crescimento da dívida pública e da relação DLSP/PIB. No entanto, a partir de 1999, com a livre flutuação do câmbio e com os ataques especulativos que antecederam e sucederam a implantação do câmbio flutuante, associados ao fato de boa parte da dívida estar indexada à taxa de câmbio, as desvalorizações do real levaram a aumentos significativos na dívida pública e, conseqüentemente, na elevação da relação DLSP/PIB. Em 2002, a desvalorização cambial representou $8,4 \%$ do PIB. A partir de 2003 , esse quadro se inverteu, o real passou a apresentar resultados positivos de valorização frente ao dólar, proporcionando uma redução da dívida pública, embora em magnitude bem inferior à verificada quando das desvalorizações. O impacto da contribuição da valorização do real na relação DLSP/PIB foi tão pequeno, que, em 2003 quando ocorreu a maior valorização cambial do período analisado (3,7\% do PIB), a relação DLSP/PIB apresentou também o valor mais alto do período analisado (52,4\%). 
Os juros foram os grandes "vilões" da dívida pública brasileira. Em todo o período analisado, os juros nominais pagos como proporção da DLSP foram extremamente altos. As altas taxas de juros, determinadas pela política monetária aplicada no Brasil em todo o período analisado, foram a principal responsável pelo aumento da dívida pública brasileira no período. No entanto, apesar da forte pressão dos juros nominais, a relação DLSP/PIB apresentou tendência crescente apenas na primeira parte do período, de 1995 a 2003, quando o crescimento do PIB foi muito fraco. Já na segunda parte, de 2004 a 2008, o forte crescimento do PIB, os bons resultados do superávit primário e a valorização cambial foram fundamentais para neutralizar os efeitos dos juros nominais e inverter a tendência da relação DLSP/PIB.

O resultado primário do governo foi muito fraco nos quatro primeiros anos do período em análise, apresentando inclusive déficit em 1996 e 1997. No entanto, a partir de 1999, o setor público consolidado passou a apresentar superávit primário de forma crescente em todos os anos. Esse crescimento deveu-se, principalmente à elevação da carga tributária, que cresceu no mesmo ritmo. Entre 1998 e 2008, o superávit primário passou de $0,0 \%$ do PIB para 4,0\% do PIB. Donde se conclui que o superávit primário foi de importância fundamental para manter a sustentabilidade de dívida pública, principalmente diante das altas taxas de juros praticadas em todo o período e, do fraco crescimento econômico obtido no período em que a relação DLSP/PIB se manteve crescente, principalmente nos anos de 1998, 1999, 2001 e 2003, quando o crescimento do PIB foi de apenas $0,1 \%, 0,8 \%, 1,3 \%$ e 1,1\%, respectivamente.

O crescimento econômico foi um dos fatores determinantes nas tendências da relação DLSP/PIB, ocorridas no período analisado. No primeiro momento, de 1995 a 2003, a tendência crescente desta dívida deveu-se ao fraco crescimento do PIB e, no segundo momento, o forte crescimento do PIB teve importância fundamental na tendência decrescente da relação DLSP/PIB. Um bom exemplo do impacto do crescimento econômico na relação DLSP/PIB foi o ano de 2003, quando ocorreu 0 maior valor da relação DLSP/PIB $(52,4 \%)$ de todo o período analisado, e o crescimento do PIB foi de apenas 1,1\%.

Com relação ao perfil da dívida pública brasileira, no período analisado constatou-se redução da dívida externa e forte elevação da dívida interna. Devido à política econômica adotada pelo governo, a partir de 2003 ocorreu um aumento no fluxo de divisas para o Brasil, elevando as reservas internacionais e contribuindo 
para a melhora dos principais indicadores de solvência externa. Dessa forma, a dívida interna tomou o lugar da dívida externa, passando a ser o principal foco de atenção da economia brasileira. A partir de 2006, as reservas internacionais foram superiores aos passivos externos, gerando resultados superavitários para o setor público na balança externa, contribuindo para redução da dívida total líquida do setor público.

Conforme constatado, através da análise dos dados apresentados nesta monografia, a sustentabilidade da dívida pública depende tanto da política fiscal quanto da política monetária adotadas. A política fiscal foi bastante restritiva, caracterizada por um superávit primário crescente na maior parte do período analisado. O aumento da carga tributária, além de cobrir os déficits contínuos e crescentes da previdência social, foi suficiente para gerar superávits primários também crescentes a partir do ano de 1999.

A tendência decrescente na relação DLSP/PIB a partir de 2004, motivada principalmente pelo superávit primário alto e crescente, pela valorização cambial e pelo crescimento da economia, demonstra que o Brasil encontrou um caminho para a gestão e sustentabilidade da sua dívida pública. No entanto, a alta carga tributária tem onerado fortemente a população brasileira, e isto significa que são necessários estudos urgentes na busca de soluções alternativas para manter essa sustentabilidade. Uma alternativa poderia ser a tão comentada "reforma da previdência social", que provocaria a redução dos seus déficits crescentes, criando condições para que o governo diminuísse a carga tributária sem impacto no resultado primário. Contudo, essa reforma necessita ser estudada com cautela, para evitar que o "tiro saia pela culatra" e os resultados sejam piores do que o atual ônus da alta carga tributária, para grande parte da população brasileira. Este assunto pode ser uma boa sugestões para trabalhos futuros. 


\section{REFERÊNCIAS}

ARTESP. Programa de concessões rodoviárias garante $\mathbf{R} \$ 15,6$ bilhões para as rodovias paulistas. Releases, fev. 2007. Disponível em:

$<\mathrm{http}: / / \mathrm{www}$. artesp.sp.gov.br/releases/releases.asp?idNoticia=1885>. Acesso em: 03 fev. 2009.

BACEN. Trajetória do endividamento líquido e critérios de valorização do PIB. Relatório de Inflação, dez. 2004. Disponível em:

<http://www.bcb.gov.br/htms/relinf/port/2004/12/ri200412b3p.pdf>. Acesso em: 24 mar. 2009.

BARBOSA, G.L.B. A sustentabilidade da política fiscal brasileira no período pós-Real: 1995-2006. 2007. 138 f. Dissertação (Mestrado em Administração, modalidade profissionalizante) - Universidade Federal da Bahia - UFBA, Salvador, 2007.

CARVALHO, M.A.S. Privatização, dívida e déficit públicos no Brasil. Rio de Janeiro, nov. 2001. IPEA (texto para discussão oํ 847).

CARVALHO FILHO, J.S. Estado mínimo x Estado máximo: 0 dilema. Revista Eletrônica sobre a Reforma do Estado, Salvador, N.12, dez. 2007/fev. 2008.

Disponível em: <http://www.direitodoestado.com/revista/RERE-12-DEZEMBRO-2007JOSE DOS SANTOS CARVALHO.pdf>. Acesso em: 03 fev. 2009.

CASTRO, F.J. A variação da dívida pública brasileira entre 1995 e 2005 Fatores determinantes. 2007. 142 f. Dissertação (Mestrado em economia) Pontifícia Universidade Católica de São Paulo, São Paulo, 2007.

CORREIA, F.M; MEURER, R. Política fiscal, sustentabilidade da dívida pública e liquidez dos títulos: Uma análise para o Brasil. Estudos Econômicos, São Paulo, V. 38, N. 3, P. 639-667, jul./set. 2008.

GALLE, J. M; BERTOLLI, S. A. A dívida pública brasileira pós-Plano Real. Intertem@ s ISSN 1677-1281, 2008 - intertemas.unitoledo.br. Disponível em: <http://intertemas.unitoledo.br/revista/index.php/Juridica/article/viewFile/203/203>. Acesso em: 01 fev. 2009.

GIAMBIAGI, F. Cenários para a relação dívida pública/PIB: Simulações e perspectivas de redução da carga tributária e da relação gasto corrente/PIB. Revista do BNDES, Rio de Janeiro, V. 13, N. 26, P. 163-190, dez. 2006. 
GIAMBIAGI, F.; ALÉM, A.C. Finanças públicas: Teoria e prática no Brasil. 2.ed. Rio de Janeiro: Campus, 2001. P.227.

GOLDFAJN,I.; PAULA, A. Uma nota sobre a composição ótima da dívida pública - reflexões para o caso brasileiro. Rio de Janeiro, dez. 1999. PUC-RIO (texto para discussão $\mathrm{n}^{0}$ 411).

GRYZER, A.M.M. A evolução da dívida pública brasileira de 1994 a 2004.2006. 74 f. Dissertação (Mestrado em Economia, modalidade profissionalizante, com ênfase em Mercados Financeiros) - Universidade Federal do Rio Grande do Sul UFRGS, Porto Alegre, 2006.

MEDRANO, L. A. T.; MENDONÇA, M. J. C.; PIRES, M. C. Administração e sustentabilidade da dívida pública no Brasil: Uma análise para o período 19952007. Rio de Janeiro, jul. 2008. IPEA (texto para discussão no 1.342).

OLIVEIRA, J.C. Uma análise das condições de sustentabilidade de curto e médio prazo da dívida pública brasileira. 2005. 131 f. Dissertação (Mestrado em Desenvolvimento Econômico) - Universidade Federal do Paraná, Curitiba, 2005.

PÊGO FILHO, B.; PINHEIRO, M. M. S. Os passivos contingentes e a dívida pública no Brasil: Evolução recente (1996-2003) e perspectivas (2004-2006). VIII Prêmio, out. 2003. Disponível em:

<http://www.tesouro.fazenda.gov.br/premio_TN/VIIIPremio/1premio_afdp.pdf>. Acesso em: 05 fev. 2009.

PÊGO FILHO, B.; PINHEIRO, M. M. S. Os passivos contingentes e a dívida pública no Brasil: Evolução recente (1996-2003) e perspectivas (2004-2006). Brasília, jan. 2004. IPEA (texto para discussão no 1.007).

SILVA, E.L.; MENEZES, E M. Metodologia da pesquisa e elaboração de dissertação. 3.ed. Florianópolis: UFSC, 2001. Disponível em: $<$ http://projetos.inf.ufsc.br/arquivos/Metodologia da Pesquisa 3a edicao.pdf>. Acesso em: 03 fev. 2009. 